(C) Emily Mick, 2020

\title{
Hydrothermal alteration and sealing at Turrialba as a mechanism for phreatic eruption triggering
}

\author{
Emily Mick \\ Department of Earth and Planetary Sciences \\ McGill University, Montreal
}

August 2020

A thesis submitted to McGill University in partial fulfillment of the requirements of the degree of Master of Science

(C) Emily Mick, 2020 


\section{Abstract}

Turrialba is a basaltic to andesitic Holocene stratovolcano that after decades of quiescence reactivated in 1996 and has been highly active ever since. Turrialba is characterized by a highly active magmatic-hydrothermal system, and we propose that hydrothermal sealing and volatile accumulation are the mechanisms responsible for the reactivation and persistent phreatic activity at Turrialba since 2010. Evidence of sealing is found in pyroclastic breccias from phreatic eruptions as high concentrations of hydrothermal minerals coupled with low intrinsic permeability. The suite of volcanic breccias studied herein erupted from the main vent between 2014 and 2019 and has an alteration mineral assemblage of $\mathrm{SiO}_{2}$ polymorphs \pm gypsum \pm natroalunite \pm pyrite. The mineral assemblage is indicative of acid sulphate alteration within the advanced-argillic alteration facies characterized by temperatures of approximately $200-350^{\circ} \mathrm{C}$ as indicated by the presence of gypsum and natroalunite, the high temperature endmember of the alunite series. Acid sulphate alteration is the result of extreme base leaching by acidic fluids $(\mathrm{pH}<4)$ with a high sulphate content. Measurements of permeability and porosity yielded variable porosity and very low to non-existent permeability in all hydrothermal breccia samples. Back-scatter electron (BSE) images reveal nano-, micro- and macro-scale fracture networks discontinuously filled with hydrothermal gypsum and pyrite which are responsible for diminished permeability, supporting the conclusion that hydrothermal sealing is active at Turrialba. Diminished permeability associated with the formation of a seal inhibits the escape of gases, causing them to accumulate below the seal and pressurize the system. Eventual seal failure due to overpressure results in the frequent phreatic eruptions seen at Turrialba. 


\section{Résumé}

Turrialba est un stratovolcan de composition basaltique à andésitique de l'Holocène qui, après des décennies de quiescence, s'est réactivé en 1996 et est resté très actif depuis. Turrialba se caractérise par un système magmatique-hydrothermal très actif, et nous proposons que le scellage hydrothermal et l'accumulation de gaz soient les mécanismes responsables pour la réactivation et l'activité phréatique persistante à Turrialba depuis 2010. Une abondance de minéraux hydrothermaux, ainsi qu'une basse perméabilité dans les brèches pyroclastique est considérée comme les évidences possibles que le scellage s'est produit. Un assemblage de minéraux d'altération comprenant $\mathrm{SiO}_{2} \pm$ gypse \pm natroalunite \pm pyrite a été identifié indique une altération d'acide de sulfate dans le faciès d'altération argileuse avancée caractérisé par des températures d'environ $200-350^{\circ} \mathrm{C}$. L'altération d'acide de sulfate est le résultat d'une lixiviation extrême par des fluides acides $(\mathrm{pH}<4)$ avec un contenu en sulfate élevée. Les mesures de perméabilité et de porosité ont donné une porosité variable et une perméabilité très faible à inexistante dans toutes les brèches hydrothermales. Les images d'électrons rétrodiffusés montrent des réseaux de fractures comprennent des fractures de tailles nano, micro et macro remplis de manière variable de gypse et de pyrite qui sont responsables pour la diminution de la perméabilité, soutenant la conclusion que le scellage hydrothermal est actif à Turrialba. La combinaison de minéraux hydrothermaux abondant et de basse perméabilité supporte la théorie que le scellage hydrothermal est responsable pour l'activité phréatique fréquent a Turrialba. Une éventuelle rupture du scellé due à une surpression entraîne les fréquentes éruptions phréatiques observées à Turrialba. 
(C) Emily Mick, 2020

\section{Preface}

This thesis is composed of original research conducted by the author at the Department of Earth and Planetary Sciences, McGill University, under the supervision of Dr. John Stix. Fieldwork, sample preparation, laboratory analysis, and data interpretation were conducted by the author between 2018 and 2020. This thesis is based on one manuscript intended for publication in a peerreviewed journal. The author is the main contributor and first author of the article. The manuscript is entitled Hydrothermal alteration and sealing at Turrialba as a mechanism for phreatic eruption triggering and is co-authored by John Stix and J. Maarten de Moor. All co-authors have contributed intellectually and provided guidance in the collection, analysis, and/or interpretation of data. 


\section{Acknowledgements}

First and foremost, I would like to thank my supervisor John Stix for his unending patience and invaluable guidance through the course of my Masters thesis; his passion and excitement for research inspire and motivate me on a daily basis. I would also like to thank J. Maarten de Moor for sharing his Turrialba expertise and samples; without his assistance this project would not have been possible. I would like to thank Bruce Christenson for his invaluable insights into hydrothermal sealing. I would like to thank the incredible team at INRS Quebec City, in particular Felix-Antoine Comeau and Jasmin Raymond, for sharing their analytical expertise and facilities. I would like to thank my committee members, professors, colleagues, and the staff at the Department of Earth and Planetary Sciences of McGill University, especially my volcano family (Clara Waelkens, Fiona D’Arcy, Jessica Salas-Navarro, Shane Rooyakkers, Robert Bogue and Stephen Oni). In particular I would like to thank Christie Rowe and Lang Shi with the XRD and SEM, respectively, as well as the McGill Cell Imaging and Analysis Network (Hans Larsson and Rui Tahara) for their patience and analytical expertise. I would also like to thank the amazing graduate students who inspired and supported me throughout this experience, especially Jessica Salas-Navarro, Debarati Das, Brindley Smith, Clara Waelkens and Fiona D’Arcy, thank you all for brightening my days. I would like to thank my siblings both real and chosen, Douglas Mick, Jackson Mick and Sabrina Bailey for their encouragement, honesty and for always listening. Lastly, I would like to thank my parents, Laurie and Bill Mick, for being my biggest cheerleaders and believing in me when even I didn't, my achievements are and will always be a testament to the unwavering love and support they have given me from day one. 


\section{Table of Contents}

Abstract......................................................................... 2

Résumé................................................................... 3

Preface........................................................................ 4

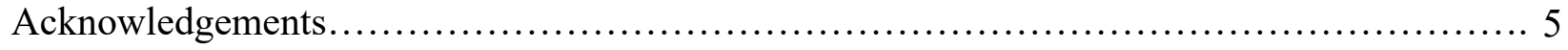

Table of Contents.......................................................... 6

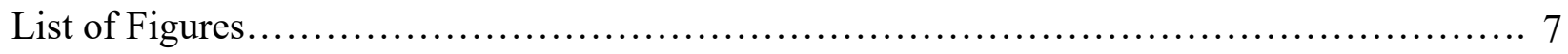

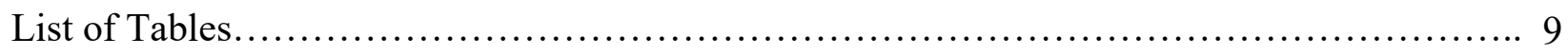

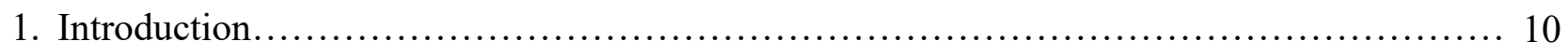

2. Hydrothermal alteration and sealing at Turrialba as a mechanism for phreatic eruption

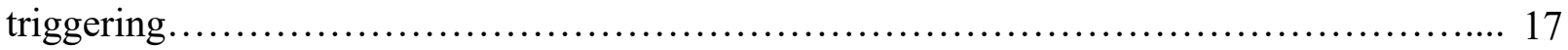

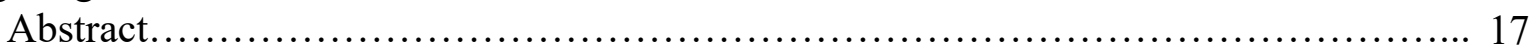

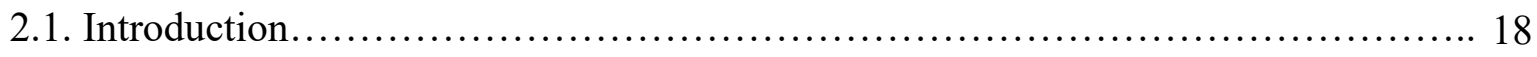

2.1.1. Phreatic Eruptions and Hydrothermal Sealing......................... 18

2.1.2. Turrialba Volcano............................................... 20

2.1.3. Eruptive History............................................... 20

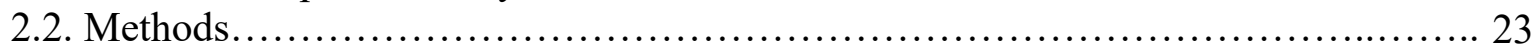

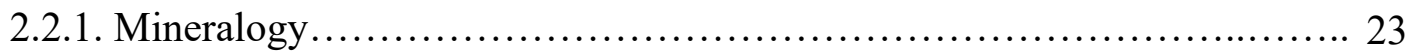

2.2.2. Physical Properties............................................... 24

2.2.3. Fracture Analysis................................................. 25

2.3. Results........................................................... 26

2.3.1. Mineral Assemblage............................................. 26

2.3.2. Physical Properties............................................. 31

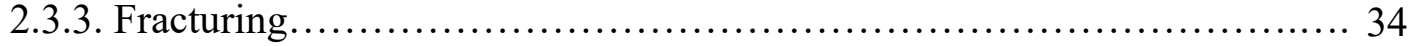

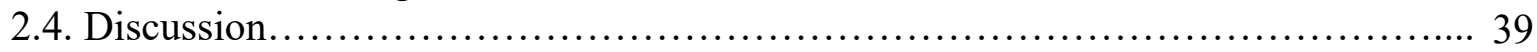

2.4.1. Examples of Hydrothermal Sealing and Phreatic Eruptions: Ruapehu and Ontake....................................................... 40

2.4.2. Hydrothermal Alteration at Turrialba................................. 42

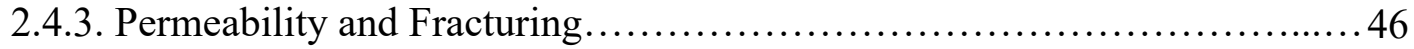

2.4.4. Hydrothermal Sealing at Turrialba.................................. 49

2.4.5. Hydrothermal Sealing Model..................................... 51

2.5. Conclusions............................................................ 52

2.6. Appendix I. Supplementary XRD Data................................. 55

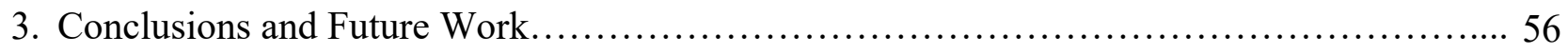

References................................................................... 58 


\section{List of Figures}

Figure 1: A. Map of Costa Rica showing the location of Turrialba and other Costa Rican volcanoes of the Central American Volcanic Arc. B. View of Turrialba showing a faint gas plume amongst the clouds. C. View of the summit region of Turrialba showing the active west crater and the 2019 sampling area outlined in dotted yellow.....

Figure 2: Back-scattered electron (BSE) images. A: A large orthopyroxene crystal that has been partially altered to $\mathrm{SiO}_{2}$. Sample T-18-11-07-R8. B: A thin gypsum-filled fracture cutting an area of fine-grained natroalunite. Thin open fractures cut small pseudomorphed crystals. Sample T-1504-18-R1. C: A vesicle partially filled by generations of $\mathrm{SiO}_{2}$ and natroalunite seen as bands moving towards the center of the vesicle, all cut by younger open fractures. Sample T-18-11-07R9. D: Continuous gypsum veins cutting a natroalunite matrix with discrete gypsum crystals. A pseudomorphed crystal of an unknown original composition now composed of mostly $\mathrm{SiO}_{2}$ is also seen. Sample T-15-04-18-R1. E: Gypsum-filled fractures intersecting gypsum-filled vesicles in a vesicular basalt clast. Sample T-19-04-28-R8B. F: A thin vein of gypsum lined with pyrite that has been disseminated into the surrounding natroalunite matrix. Sample T-19-04-28-R8B.......28

Figure 3: Porosity (\%) at $500 \mathrm{psi}$ as a function of gas permeability (mD). B: Bulk density $\left(\mathrm{kg} / \mathrm{m}^{3}\right)$ as a function of gas permeability $(\mathrm{mD})$

Figure 4: Proportions of terminations, abutments and crossings illustrate the degree of connectivity among pyroclastic breccia samples. A: General connectivity taking into consideration fractures at all scales. Intersections (abutments and crossings) are present in a higher proportion than terminations, indicating a high degree of connectivity. B: Connectivity features divided into five spatial scales. Intersections (abutments and crossings) are present in a higher proportion than terminations at all scales, demonstrating the general insensitivity of scale. C: Back-scattered electron (BSE) images showing examples of abutments, terminations and crossings.............35

Figure 5: Back-scattered electron (BSE) images. A: Continuous open and anastomosing fractures transecting a pseudomorphed crystal. B: Open macro-fractures and anastomosing micro-fractures. C: Open continuous micro-fractures and nano-fractures within a basalt clast. D: Smooth walled fractures within a basalt clast surrounded by matrix containing rough walled fractures. E: Open, anastomosing, irregular macro-fractures within the matrix. F: Large filled fracture within a

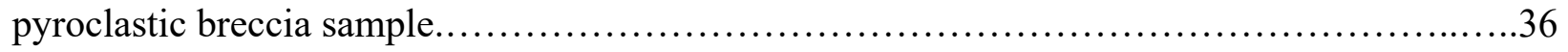

Figure 6: A: Distribution of macro-scale fractures with a width $>10 \mu \mathrm{m}$, micro-fractures with a width of 1-10 $\mu \mathrm{m}$ and nano-scale fractures with a width $<1 \mu \mathrm{m}$. B: Distribution of filled and open

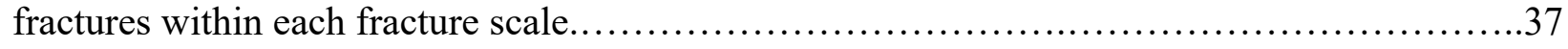

Figure 7: Back-scattered electron (BSE) images. A: Discontinuous filling of a fracture travelling through matrix and clast material. B: Discontinuous filling of a matrix fracture. In each image, fractures show both open and filled segments........................................... 
Figure 8: Four consecutive vertical core slices obtained by CT-imaging showing the 3dimensional connectivity of fractures. Each image is separated by a thickness of 40

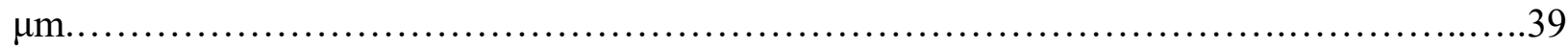

Figure 9: Diagram of hydrothermal sealing at Turrialba adapted from Stix and de Moor (2018). Magmatic gases originating in the magma reservoir extending from between $1-10 \mathrm{~km}$ below the surface up to depths of $30 \mathrm{~km}$ (Di Piazza et al., 2015) enter the shallow hydrothermal system (Rizzo et al., 2016). Newly formed hot $\left(200-350^{\circ} \mathrm{C}\right)$, acidic $(\mathrm{pH}<4)$ fluids cause the dissolution of primary igneous minerals and the precipitation of hydrothermal minerals within the permeable

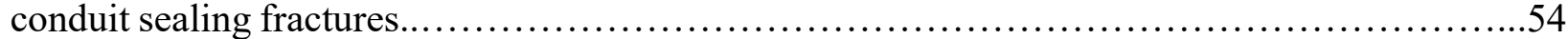




\section{List of Tables}

Table 1: Weight percent of matrix mineralogy of pyroclastic breccias determined by XRD. Data reduction was performed using PDF-4 Minerals 2019 RBD and PDXL2 Rigaku Data Analysis Software was used to confirm results. $\mathrm{SiO}_{2}$ includes both quartz and cristobalite. Natroalunite includes natroalunite-1c, natroalunite-2c, and huangite. Only major minerals were included. All values are approximate and rounded to the nearest 5\%. The term "present" denotes values $<5 \%$. Trace minerals including windhoekite, mawsonite, ankerite, $\mathrm{ZnS}$ and $\mathrm{Al}_{2}\left(\mathrm{SO}_{4}\right)_{3}$ were each identified on one occasion with $\mathrm{wt} \% \leq 5 \%$ but were omitted due to a lack of certainty associated with their low abundance and low occurrence. Full results including trace minerals and unrounded $\mathrm{wt} \%$ available in supplementary data.............................................29

Table 2: Alteration assemblage and original mineralogy for pyroclastic breccia samples determined using $\mathrm{SEM}$. $\mathrm{SiO}_{2}$ includes both quartz and cristobalite.

Table 3: Physical properties of selected hydrothermal breccias and fresh scoria samples (T-19-0428-R1 and T-19-04-28-R12). Porosity at room temperature determined by grain volume. Porosity at 500 psi and gas permeability determined by a combined gas permeameter/porosimeter. Liquid permeability determined using a Klinkenberg correction. .33

Table 4: Detailed weight percent of matrix mineralogy of pyroclastic breccias determined by XRD. Data reduction was performed using PDF-4 Minerals 2019 RBD and PDXL2 Rigaku Data Analysis Software was used to confirm results. $\mathrm{SiO}_{2}$ includes both quartz and cristobalite. Natroalunite includes natroalunite-1c, natroalunite-2c, and huangite $\ldots \ldots \ldots \ldots \ldots \ldots \ldots \ldots \ldots . \ldots \ldots 5$ 


\section{Introduction}

Phreatic eruptions are caused by the rapid expansion of a vapor phase that occurs without the expulsion of solid juvenile magmatic material (Barberi et al., 1992). Generally, the rapid expansion of the vapor phase is due to the transfer of heat from a magmatic source into the hydrothermal system or shallow aquifer above, but this is not an absolute necessity (Barberi et al., 1992; Stix and de Moor, 2018). Eruptive products are dominated by pyroclastic breccias and fall deposits within the immediate vicinity of the crater area, but there is also a danger to the surrounding population due to the release of toxic gases as well as base surges and lahars that may be produced (Barberi et al., 1992). The greatest source of danger associated with phreatic eruptions, however, is the lack of warning that would allow for adequate safety precautions to be enacted.

Some progress has been made in identifying the precursors to phreatic eruptions but, as of yet, they remain unreliable. The most reliable precursor is the occurrence of banded tremor prior to eruptions. However, these signals are not necessarily indicative of a phreatic eruption, as they are also associated with other types of eruptions, for instance strombolian (Barberi et al., 1992; Stix and de Moor, 2018). Variations in gas flux have also been found to be associated with phreatic eruptions. de Moor et al. (2016b) found that the proportions of certain gases varied in the months to years prior to phreatic eruptions, and that phreatic eruptions were at least three times more likely to be associated with high $\mathrm{SO}_{2} / \mathrm{CO}_{2}$ values within a reasonable time window. However, the variability in this precursory signal makes it difficult to implement accurately.

Phreatic eruptions themselves are frequently precursors to larger magmatic eruptions, for example the devastating May $18^{\text {th }}, 1980$ eruption of Mt. St. Helens, so understanding their cause or causes is paramount to ensuring the safety of surrounding communities (Global 
Volcanism Program, 1980). However, it can be difficult to distinguish between different types of phreatic eruptions, necessary in determining the presence of a magmatic component in order to predict future magmatic eruptions (Barberi et al., 1992). Fluids are an essential component in phreatic eruptions and can be derived either from the upward migration of magmatic gases or the downward movement of meteoric waters. Here we focus on phreatic eruptions at volcanoes whose hydrothermal systems are fed by magmatic gases as exemplified at Turrialba volcano, Costa Rica. These eruptions can be broken down into two categories. Type 1 eruptions are those where magmatic gases are periodically released into the hydrothermal system either due to an intrusion, crystallization or a combination of the two (Stix and de Moor, 2018). Type 2 eruptions are those associated with increasing magmatic gas input into a crater lake resulting in the rise of the vaporliquid boundary causing vaporization of confined fluids and leading to pressurization (Stix and de Moor, 2018). Of these Turrialba hosts type 1 phreatic eruptions.

Turrialba is a Holocene stratovolcano in Costa Rica. Located 60 kilometers from the capital, San José, Turrialba is the southernmost volcano of the Central American Volcanic Arc (CAVA) in the country. The CAVA is the result of the subduction of the Cocos plate beneath the Caribbean plate at a low angle (40 degrees) at a rate of approximately $70-85 \mathrm{~mm}$ per year (Whattam and Stern, 2015; de Moor et al., 2016a). The resulting arc extends from Costa Rica to the Mexico/Guatemala border (Whattam and Stern, 2015). Turrialba stands at $3349 \mathrm{~m}$ a.s.1., second only to its neighbour Irazú with whom it shares a common base roughly 60 kilometers by 45 kilometers and whose crater is only 10 kilometers away (Martini et al., 2010; de Moor et al., 2016a). Turrialba and Irazú are also believed to have a common magmatic system. A low-density body located 1-10 kilometers below the craters is believed to be a joint magma reservoir extending 
to a maximum depth of 30 kilometers (Di Piazza et al., 2015). Turrialba hosts three craters within a 1.2-kilometer-long depression, oriented northeast-southwest (Di Piazza et al., 2015). The east, central and west craters decrease in age from east to west, with the western crater having formed during the 1864-1866 eruption (see below); this remains the only currently active crater (Martini et al., 2010). The summit area is characterized by normal faults oriented northeast-southwest, with the primary fault known as the Falla Ariete (Di Piazza et al., 2015). Turrialba is characterized by a shallow hydrothermal system and abundant fumarolic activity (Vaselli et al., 2010; Campion et al., 2012; Rizzo et al., 2016).

Eruptive products at Turrialba are predominantly basaltic to andesitic but with a complicated isotopic signature. Trace elements and radiogenic isotopes indicate two distinct mantle sources of Turrialba eruptive products: a MORB component as expected and an OIB component reflecting the subduction of the Galapagos seamount (Di Piazza et al., 2015). Furthermore, ${ }^{3} \mathrm{He} /{ }^{4} \mathrm{He}$ values (7.0-8.1) are typical of those seen at arc volcanoes (7.0-8.0) and are consistent with a slightly back of the arc position (Di Piazza et al., 2015; de Moor et al., 2016a). Current degassing includes significant $\mathrm{SO}_{2}$ with the volcano having released approximately 2.04 Mt of $\mathrm{SO}_{2}$ between 2008 and 2016, indicative of the emplacement of $0.3 \mathrm{~km}^{3}$ of magma likely to have occurred between 1998 and 2008 (de Moor et al., 2016a). In addition, the current degassing indicates that the magma composition is unchanged since 1864-1866 (Di Piazza et al., 2015).

Prior to its current period of activity Turrialba experienced six major eruptions: in 1500 B.C., 1420 B.C., 800 B.C., 50 C.E., 650 C.E. and lastly in 1864-1866 (Soto 1988; Alvarado, 1989). The last major eruption at Turrialba began on August $17^{\text {th }}, 1864$, when ash fall reached as far as the capital of San José (Reagan et al., 2006). Phreatic eruptions originated in the western crater 
and continued throughout most of the two-year eruption, producing ash columns that repeatedly distributed ash throughout the Central Valley. In the final two months of the eruption, juvenile basaltic clasts were ejected from the central crater during a period of phreatomagmatic activity. A final phreatic eruption from the western crater followed (Reagan et al., 2006). After the final eruption in 1866, Turrialba entered a period of quiescence lasting until 1996, when reactivation was detected (Reagan et al., 2006; Campion et al., 2012). Reactivation was manifested as both increasing seismicity and degassing. Significant seismic swarms occurred in 2001, 2003, 2004, 2005 and 2007, each associated with increased gas flux and the opening of new fumarolic vents (Martini et al., 2010).

The current period of eruptive activity began on January $5^{\text {th }}, 2010$, when a phreatic eruption opened a new fumarolic vent within the west crater (de Moor et al., 2016a). A second phreatic eruption took place on January $12^{\text {th }}, 2012$, again opening a new vent in the west crater. On May $21^{\text {st }}, 2013$, both the 2010 and the 2012 vents experienced simultaneous gas dominated eruptions (Global Volcanism Program, 2012; de Moor et al., 2016a). On October 29 $9^{\text {th }}, 2014$ Turrialba again erupted. This phase of activity lasted until December $8^{\text {th }}$ of the same year and included both phreatic and phreatomagmatic activity (de Moor et al., 2016a; Alvarado et al., 2016; Global Volcanism Program, 2017). Since 2014 Turrialba has experienced nearly continuous degassing and frequent ash emissions (Global Volcanism Program, 2015; Global Volcanism Program, 2017; Global Volcanism Program, 2018; Global Volcanism Program, 2019). In 2017, fresh magmatic material was identified, up to $50 \%$ of the eruptive products at the time, indicating that for a period the system was able to tap magma from a shallow source below (de Moor et al., 2017).

Turrialba hosts an active magmatic-hydrothermal system. Three phases of activity have been identified since reactivation in 1996. The first phase from 1996 to 2000 was characterized by 
low, constant seismicity accompanied by small fumarolic emissions from which magmatic components (e.g., $\mathrm{SO}_{2}$ ) had been scrubbed by the hydrothermal system (Vaselli et al., 2010; Martini et al., 2010). The second phase, from 2001 to 2007, saw increases in seismic activity and ground deformation as well as increased fumarolic activity and magmatic contributions. The final phase, beginning in 2007, was marked by an important increase in fumarolic output and the transition to a composition dominated by magmatic fluids and ongoing seismic activity. This activity is consistent with a progressive drying of the hydrothermal system by the intrusion of fresh magma (Moretti et al., 2018).

The frequent phreatic eruptions at Turrialba since its reactivation are believed to be the result of hydrothermal sealing (de Moor et al., 2016a, Stix and de Moor., 2018). Hydrothermal sealing is a process by which fluids circulating within the magmatic-hydrothermal system below a volcano precipitate minerals within the vent area, reducing the permeability, essentially sealing the conduit, and decreasing or stopping the escape of gases (Marinelli, 1969; Christenson et al., 2010; Stix and de Moor, 2018). Once unable to escape, gases accumulate and with them pressure until an overpressure threshold is reached and the seal fails, triggering a phreatic eruption. Rocks forming the seal will therefore have low intrinsic permeability and display signs of extensive hydrothermal alteration (Christenson et al., 2010; Stix and de Moor, 2018).

Turrialba is believed to be experiencing sealing due to the behaviour of gases observed during several eruptions. In the weeks prior to the October $29^{\text {th }}, 2014$ eruption, de Moor et al. (2016a) noted that $\mathrm{CO}_{2} / \mathrm{S}_{\mathrm{t}}$ experienced a dramatic increase coupled with a decrease in $\mathrm{H}_{2} \mathrm{~S}_{/} \mathrm{SO}_{2}$, while both $\mathrm{SO}_{2}$ and $\mathrm{CO}_{2}$ flux values were very low. Following the December $9^{\text {th }}, 2014$ eruption, the same study noted a dramatic increase in gas fluxes immediately following the eruption. An 
increase in $\mathrm{CO}_{2} / \mathrm{S}_{\mathrm{t}}$ was again noted in the weeks prior to the eruption on March $8^{\text {th }}, 2015$. Along with erratic pre-eruptive gas fluxes, a sudden increase in gas flux after an eruption is believed to be strong evidence for hydrothermal sealing (Christenson and Tassi, 2015).

Sealed volcanic systems present a serious hazard, not simply because they result in phreatic eruptions that can be dangerous to surrounding communities. Sealing inhibits the escape of gas which therefore limits the use of gases as precursory signals (de Moor et al., 2016b). Additionally, phreatic eruptions due to sealing are possible in passively degassing systems where sealing may have begun prior to entering the passive degassing stage, which can lead to eruptions during a period otherwise believed to be safe (Christenson et al., 2010). An additional hazard is present following the rupture of a seal when the removal of a large volume of the vapor phase from the hydrothermal reservoir can cause rapid boiling of the liquid phase, triggering further explosive activity, as was the case at Ontake volcano in Japan in 2014 (Kaneko et al., 2016). Several factors affect the overpressure and failure of a hydrothermal seal. Firstly, the depth of the seal and hydrothermal system can have an important effect on sealing, as shallow seals require less pressure to fail, and shallow hydrothermal systems cause less overpressure due to a comparatively small lithostatic overburden (Stix and de Moor, 2018). Another important consideration is the strength of the rock forming the seal. A stronger rock will be able to withstand higher pressures before cracking. Therefore, a seal formed within stronger rocks will likely require higher pressures for the seal to fail. Furthermore, sealing happens by degrees and does not need to be complete for pressure to accumulate causing an eruption. The volume of magma will also have an important impact given that it is the source of the gases (Stix and de Moor, 2018).

The objective of this thesis is to identify the mechanism or mechanisms responsible for the frequent phreatic eruptions at Turrialba observed since 2010, which have been hypothesized to be 
the result of hydrothermal sealing. Through a mineralogical study we identify the alteration mineralogy present which in turn serves to identify the properties of the fluids responsible for the alteration. A permeability and porosity study examines the effects of the alteration on the physical properties of the rocks. Coupled with a fracture study, this allows for an understanding of connectivity within and below the vent area. By integrating these analyses, we develop a model for hydrothermal sealing at Turrialba and other volcanoes with similar characteristics.

At present, reliable eruption precursors for phreatic eruptions do not exist. This research was conducted in the hope that a better understanding of the mechanism causing phreatic eruptions at Turrialba will lead to be better understanding of phreatic eruptions in general. 


\title{
2. Hydrothermal alteration and sealing at Turrialba as a mechanism for phreatic eruption triggering
}

Emily Mick ${ }^{1}$, John Stix ${ }^{1}$, J. Maarten de Moor ${ }^{2}$

${ }^{1}$ Department of Earth and Planetary Science, McGill University, 3450 University Street, Montreal, QC H3A 0E8, Canada

${ }^{2}$ Observatorio Volcanológico y Sismológico de Costa Rica (OVSICORI), Costa Rica

Key Words: Hydrothermal Sealing, Turrialba Volcano, Acid-Sulphate Alteration, Permeability

\begin{abstract}
Turrialba is a basaltic to andesitic Holocene stratovolcano that after decades of quiescence reactivated in 1996 and has been highly active ever since. Turrialba is characterized by a highly active magmatic-hydrothermal system, and we propose that hydrothermal sealing and volatile accumulation are the mechanisms responsible for the reactivation and persistent phreatic activity at Turrialba since 2010. Evidence of sealing is found in pyroclastic breccias from phreatic eruptions as high concentrations of hydrothermal minerals coupled with low intrinsic permeability. The suite of volcanic breccias studied herein erupted from the main vent between 2014 and 2019 and has an alteration mineral assemblage of $\mathrm{SiO}_{2}$ polymorphs \pm gypsum \pm natroalunite \pm pyrite. The mineral assemblage is indicative of acid sulphate alteration within the advanced-argillic alteration facies characterized by temperatures of approximately $200-350^{\circ} \mathrm{C}$ as indicated by the presence of gypsum and natroalunite, the high temperature endmember of the alunite series. Acid
\end{abstract}


sulphate alteration is the result of extreme base leaching by acidic fluids $(\mathrm{pH}<4)$ with a high sulphate content. Measurements of permeability and porosity yielded variable porosity and very low to non-existent permeability in all hydrothermal breccia samples. Back-scatter electron (BSE) images reveal nano-, micro- and macro-scale fracture networks discontinuously filled with hydrothermal gypsum and pyrite which are responsible for diminished permeability, supporting the conclusion that hydrothermal sealing is active at Turrialba. Diminished permeability associated with the formation of a seal inhibits the escape of gases, causing them to accumulate below the seal and pressurize the system. Eventual seal failure due to overpressure results in the frequent phreatic eruptions seen at Turrialba.

\subsection{Introduction}

Phreatic eruptions are caused by the violent explosion of steam without the involvement of juvenile material resulting in lithic pyroclastic breccias and fall deposits (Barberi et al., 1992). Phreatic eruptions frequently have little to no warning, and the unpredictable nature of these eruptions places them among the most dangerous eruptions in crater areas. However, a lack of solid juvenile material does not imply that magma is not a factor in these eruptions; in many phreatic events magma plays an important role as the source of volatiles and heat that drive eruptions. This is the case when hydrothermal sealing is responsible for eruptions.

\subsubsection{Phreatic Eruptions and Hydrothermal Sealing}

Hydrothermal sealing is a process by which fluids circulating in the magmatic-

hydrothermal system below a volcano precipitate minerals within the vent area, reducing the permeability and essentially sealing the conduit by decreasing or stopping the escape of gases 
(Marinelli, 1969; Christenson et al., 2010; Stix and de Moor, 2018). Trapped below the seal, gases can accumulate until an overpressure threshold is reached and the seal fails, triggering a phreatic eruption (Marinelli, 1969; Stix and de Moor, 2018). Rocks forming the seal will therefore have low permeability and display signs of extensive hydrothermal alteration. The mineralogy of the seal will vary based on fluid chemistry and temperature and can include silica, clays and sulphurbearing minerals (Stix and de Moor, 2018). The gases can be a mixture of hydrothermally-derived and magmatic gases. The depth of the seal, as well as the depth of the hydrothermal system, play important roles in the failure process. Shallow seals require less pressure to fail, and shallow hydrothermal systems cause less overpressure due to a comparatively small lithostatic overburden (Stix and de Moor, 2018). Explosive eruptions are frequently preceded by measurable increases in $\mathrm{SO}_{2} / \mathrm{CO}_{2}$, but the presence of a seal partially or fully preventing the escape of gases may have a significant impact on this important monitoring tool (de Moor et al., 2016b). A better understanding of this process is necessary to improve hazard management associated with such eruptions.

Since explosive eruptions resumed at Turrialba in 2010, phreatic eruptions have been frequent. Hydrothermal sealing has been proposed as a mechanism for the persistent phreatic activity at Turrialba, but to date, no detailed study has been conducted to examine this concept (Stix and de Moor, 2018). Hence the goal of this study is to examine the subsurface processes responsible for phreatic eruptions at Turrialba, with general application elsewhere. For this study, a suite of pyroclastic breccia samples collected from the crater of Turrialba following phreatic eruptions in 2014, 2016, 2018 and 2019 were analyzed for their mineralogy and physical properties in order to examine the evidence of hydrothermal sealing. In addition, we propose a model for the 
occurrence of sealing and phreatic eruptions at Turrialba and address the periodic nature of these events.

\subsubsection{Turrialba Volcano}

Turrialba volcano, located roughly $60 \mathrm{~km}$ east of the capital San José, is the southernmost active volcano in Costa Rica and the second tallest stratovolcano at $3349 \mathrm{~m}$ a.s.l. (Figure 1). Turrialba is characterized by basaltic to andesitic eruptive products, an active magmatichydrothermal system and abundant fumarolic activity (Vaselli et al., 2010; Campion et al., 2012). The volcano hosts three craters, east, west and central, that decrease in age from east to west with the western crater being the only currently active crater (Martini et al., 2010). Turrialba shares a common base with Irazú volcano, whose crater is located $10 \mathrm{~km}$ away; together, the two volcanoes form the largest volcano massif in Central America (Martini et al., 2010). Both Irazú and Turrialba are part of the Central American Volcanic Arc (CAVA), which is the result of the subduction of the Cocos plate beneath the Caribbean plate at a rate of approximately $70-85 \mathrm{~mm}$ per year (Figure 1). The resulting arc extends from Costa Rica to the Mexico/Guatemala border (Whattam and Stern, 2015).

\subsubsection{Eruptive History}

In the 3500 years prior to the $20^{\text {th }}$ century Turrialba experienced six major eruptions in 1500 B.C., 1420 B.C., 800 B.C., 50 C.E., 650 C.E. and lastly in 1864-1866 (Soto 1988; Alvarado, 2009). Following the 1864-1866 eruption, Turrialba entered a period of quiescence lasting until 1996, when reactivation was first detected; however, eruptive activity did not resume until 2010 (Reagan et al., 2006; Campion et al., 2012). 
The 1864-1866 eruption of Turrialba began on August $17^{\text {th }}, 1864$, when ash fell throughout the Central Valley in Costa Rica including the capital of San José (Reagan et al., 2006). Phreatic explosions originated in the western crater and continued throughout most of the two-year period, producing ash columns that repeatedly distributed ash throughout the Central Valley. In the final two months of the eruption, January-February 1866, the eruptive character transitioned to phreatomagmatic. During this period of activity, juvenile basaltic clasts were ejected from the central crater. A final phreatic eruption from the western crater followed (Reagan et al., 2006).

Figure 1. A. Map of Costa Rica showing the location of Turrialba and other Costa Rican volcanoes of the Central American Volcanic Arc. B. View of Turrialba showing a faint gas plume amongst the clouds. $C$. View of the summit region of Turrialba showing the active west crater and the 2019 sampling area outlined in dotted yellow.

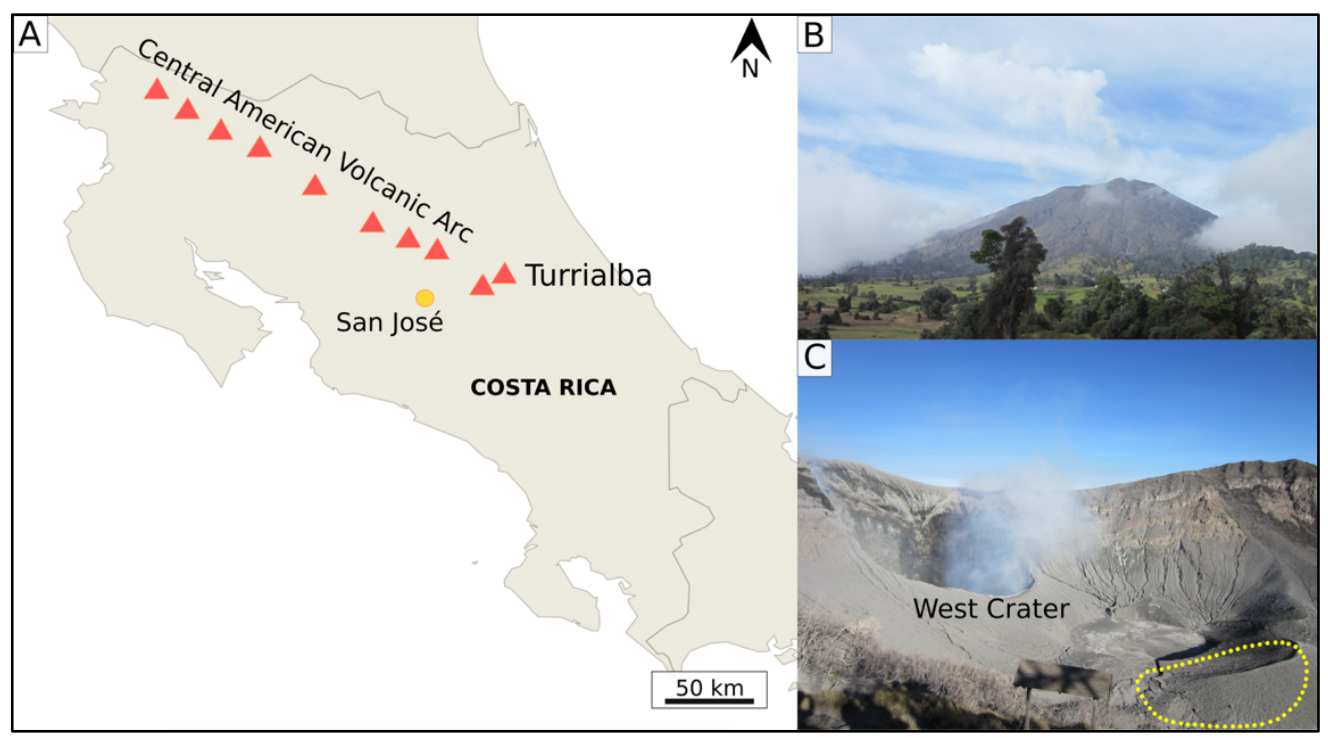

Following the 1864-1866 eruption Turrialba entered a 130-year period of quiescence until 1996 when activity resumed, as evidenced by increasing seismicity and degassing. Important seismic swarms occurred in 2001, 2003, 2004, 2005 and 2007, each associated with increased gas flux and the opening of new fumarolic vents (Martini et al., 2010). Seismicity included a 
combination of long-period (LP) and volcano-tectonic (VT) events at depths of 4 to 6 kilometers (Martini et al., 2010). Deformation during this time was measured with mixed results. Tilt measurements taken at various stations around the volcano detected inflation between 1996 and 2007; further inflation since 2010 has been detected (Martini et al., 2010; de Moor et al., 2016a).

Since reactivation in 1996 Turrialba has been carefully monitored, and three phases of activity have been identified based on both seismic activity and the activity of the magmatichydrothermal system as described by Vaselli et al. (2010) and Martini et al. (2010). The first phase, from 1996 to 2000, was characterized by low, constant seismicity accompanied by small fumarolic emissions from which magmatic components (e.g., $\mathrm{SO}_{2}$ ) had been scrubbed by the hydrothermal system. The second phase, from 2001 to 2007, saw increased seismic activity and ground deformation as well as increased fumarolic activity and magmatic contributions. The final phase, which began in 2007, was marked by an important increase in fumarolic output and the transition to a composition dominated by magmatic fluids and ongoing seismic activity.

On January $5^{\text {th }}, 2010$, eruptive activity resumed at Turrialba with a phreatic eruption, opening a new fumarolic vent within the west crater (de Moor et al., 2016a). A second phreatic eruption took place on January $12^{\text {th }}, 2012$, again opening a new vent in the west crater, and on May $21^{\text {st }}, 2013$, both the 2010 and the 2012 vents experienced simultaneous gas eruptions (Global Volcanism Program, 2012; de Moor et al., 2016a). The next event beginning on October 29 ${ }^{\text {th }}, 2014$, and lasting until December $8^{\text {th }}$ of the same year included both phreatic and phreatomagmatic activity marking a new, more vigorous phase of activity at Turrialba (Global Volcanism Program, 2017; de Moor et al., 2016a; Alvarado et al., 2016). Since 2014 Turrialba has experienced nearly continuous degassing and frequent ash emissions, phreatic eruptions have occurred repeatedly, associated with larger ash emissions; but have not been tracked separately (Global Volcanism 
Program, 2015; Global Volcanism Program, 2017; Global Volcanism Program, 2018; Global Volcanism Program, 2019). In 2017, fresh magmatic material was identified, up to 50\% of eruptive products at the time, indicating that for a period the system was open to shallow magma below (de Moor et al., 2017).

\subsection{Methods}

\subsubsection{Mineralogy}

X-ray diffraction (XRD) analysis was performed on the ash matrix of all pyroclastic breccia samples in order to identify the composition and alteration of the ash. Matrix material was first isolated using a micro-drill, taking care to avoid clasts, although clasts with a diameter less than 5 mm were difficult to avoid completely. The material was then sieved and the $<400 \mu \mathrm{m}$ fraction was placed in a tungsten carbide mill and ground for 90 seconds before being rinsed and placed back in the mill for a further 15 seconds of grinding. The sample was then dried on a watch glass in an oven at $30^{\circ} \mathrm{C}$, to avoid damaging possible clays, for up to three days until completely dry. The material was then sieved again and the $<150 \mu \mathrm{m}$ fraction used to prepare a back-packed slide. Analysis was performed using a Rigaku Smartlab X-Ray Diffractor with a copper target X-ray source and equipped with two detectors: a high-efficiency scintillation detector and a D/tex Ultra 250 high speed silicon strip 1D detector. Analyses were performed from 2-70 degrees using a step of 0.01 degrees and a speed of 1.0 seconds. The voltage was set to $40 \mathrm{kV}$ and current to $44 \mathrm{~mA}$. PDF-4 Minerals 2019 RBD software was used for data reduction, and PDXL2 Rigaku Data Analysis Software was used for confirmation, in order to ensure accuracy.

Further mineralogical analysis was performed using a scanning electron microscope (SEM) looking at both matrix and clast composition. Polished thin sections were prepared by Vancouver 
Petrographics Ltd. for a subset of 14 pyroclastic breccia samples. Preliminary mineral identification was done by transmitted light microscopy, and areas of interest were identified for detailed examination. The sections were then carbon coated, and SEM analysis was performed using a Hitachi SU5000 scanning electron microscope equipped with an energy dispersive X-ray spectrometer (EDS). Beam energy was set to $15 \mathrm{kV}$ and beam current to $20 \mathrm{nA}$. Spot intensity was set to 50 when using EDS and 30 when imaging to minimize damage while the $\mathrm{Z}$ distance was set to $10 \mathrm{~mm}$ when using EDS and $5 \mathrm{~mm}$ when imaging. EDS analysis and processing were performed using Aztec version 3.3 software from Oxford Instruments.

\subsubsection{Physical Properties}

Permeability and porosity were analyzed on a subset of 13 variably altered pyroclastic breccia and scoria samples. Seven breccia samples were omitted as they were of insufficient size for coring and analysis. Samples were first cored at INRS in Quebec City using a drill bit yielding $2.54 \mathrm{~cm}$ diameter cores through the thickest portion of the sample. The ends of each core were then cut and polished in order to form a perfect cylinder. Care was taken to limit any breakage along the edges which would alter the porosity values. All core lengths and diameters were then measured using a Mitutoyo electronic caliper, from which the volume was determined. Samples were then weighed, and density was determined. Porosity and permeability measurements were conducted using a Coretest Systems AP-603 combined permeameter-porosimeter. Porosity was first determined using grain volume measured using the Coretest Systems AP-603 and the previously determined total volume. Grain volume determinations occurred at atmospheric conditions as the chamber was unable to be pressurized. Multiple measurements of both porosity and permeability were then taken at 500 psi using nitrogen gas. Pressures of atmospheric and 500 
psi were chosen to provide a range for the permeability of samples at low and high pressure. This is important since during sealing the pressure within the system would vary as gases accumulated. The associated software then performed a Klinkenberg correction to determine equivalent nonreactive liquid permeability values. Measurements at 500 psi failed when the permeability was below the detection limit; in these cases, the permeability was taken to be $<0.001 \mathrm{mD}$, the detection limit of the instrument.

\subsubsection{Fracture Analysis}

In order to quantify the fractures, EBS imaging was conducted using the SEM with the same settings as outlined above for imaging. The same 14 pyroclastic breccias used in the mineralogical study were analyzed. Fractures were imaged at scales of $500 \mu \mathrm{m}, 400 \mu \mathrm{m}, 300 \mu \mathrm{m}$, $200 \mu \mathrm{m}$ and $100 \mu \mathrm{m}$. Fractures were then quantified in terms of connectivity using the method first described by Barton and Hsieh (1989). Connectivity was measured as the proportions of terminations, crossings and, abutments. To obtain a representative value, five fracture images at each scale were chosen, and the number of each type of fracture interaction was counted within each image. Images with the highest quality were selected for analysis in order to minimize error associated with visual identification of fractures. Care was also taken to include images from the maximum number of samples. During analysis fracture widths and wall types were also noted. Fractures were determined to fall within three scales: nano-, micro-, and macro-scale. The relative proportions of the three scales, as well as the distribution of filling by hydrothermal minerals, were then analyzed using the counting technique applied previously.

Fractures were then imaged in three dimensions within a representative breccia sample using a Xradia nano-CT instrument at the McGill Cell Imaging and Analysis Network. A 
preliminary, low-resolution scan was completed first to identify areas of interest, followed by a detailed, high-resolution scan of a smaller area. An initial scan with a pixel size of $40 \mu \mathrm{m}$ was conducted followed by a secondary scan with a pixel size of $15 \mu \mathrm{m}$. Fractures were then mapped in 3-D using Dragonfly software by Open Research Systems.

Errors associated with fracture analysis may arise from several unavoidable sources. Firstly, it is impossible to discern which fractures have been formed as the result of the eruption of the breccias. This is noteworthy as fractures formed during the eruption would not have contributed to in situ permeability and therefore would not contribute to the sealing process. Secondly, given that pyroclastic breccias cannot be visualized at their source, i.e., within the vent, it is not possible to consider features beyond the scale of the bombs. Large, outcrop-scale fractures may have had an important effect on the overall permeability but cannot be evaluated following eruption as samples are no longer in situ.

\subsection{Results}

\subsubsection{Mineral Assemblage}

All pyroclastic breccia samples show a high degree of alteration; very few samples contained any original mineralogy. However, some areas of primary igneous clinopyroxene, orthopyroxene and plagioclase are preserved in partially altered euhedral crystals (Figure 2a). An alteration mineral assemblage of $\mathrm{SiO}_{2}$ polymorphs \pm gypsum \pm natroalunite \pm pyrite was identified both within the matrix using XRD and within the clasts using SEM (Table 1, Table 2). $\mathrm{SiO}_{2}$ polymorphs including cristobalite and quartz were identified in all breccia samples as the primary component of pseudomorphed crystals as well as in the matrix as fine grain aggregates (Figure 2b, 2c). Gypsum is the primary vein-forming and fracture/vesicle-filling mineral in the products of all 
eruptions but is not present in every sample. Gypsum is manifested as fine-grained aggregates, distinct crystals and acicular needles both within the matrix and clasts (Figure 2b, 2d, 2e). Natroalunite is present primarily as fine-grained aggregates in the matrix; it is rarely seen as radiating crystals within vesicles or accompanying $\mathrm{SiO}_{2}$ in pseudomorphed crystals (Figure 2c, 2f). Like gypsum, natroalunite is present in the products of all eruptions but not all samples. Natroalunite is an aluminum sulphate mineral, which, taken in combination with the dominant tabular form of the pseudomorphed crystals indicates that plagioclase was a major component of the original mineralogy. Pyrite is present as discrete grains, varying from cubic to amorphous, usually within veins or fractures filled by gypsum (Figure 2e, 2f). Pyrite is observed only in samples from 2018 and 2019; no pyrite was identified in earlier samples and no other time-based variations were identified (Table 1, Table 2). Pyrite is the result of the interaction of $\mathrm{H}_{2} \mathrm{~S}$-bearing fluids with Fe-bearing rocks or gypsum (Zimbelman at al., 2005). This is consistent with the association seen between pyrite and gypsum at Turrialba.

Based on cross-cutting relationships among veins, fractures and crystals, an alteration paragenesis has been developed. First a stage of leaching occurred in order to make available the elements seen in the replacement mineralogy. The banding of $\mathrm{SiO}_{2}$ and natroalunite as seen in Figure $2 \mathrm{c}$, as well as the presence of both in some pseudomorphed crystals, indicates that $\mathrm{SiO}_{2}$ and natroalunite replacement occurred simultaneously although $\mathrm{SiO}_{2}$ was the dominant phase. Gypsum and pyrite appear to form a second phase of replacement as indicated primarily by gypsum veins cutting fully pseudomorphed crystals (Figure 2b). At least two stages of fracturing occurred as well. Nearly all fractures are filled with gypsum rather than natroalunite or $\mathrm{SiO}_{2}$, indicating that these fractures were likely formed after the initial stage of alteration. Many open and filled fractures also cut areas of $\mathrm{SiO}_{2}$ and natroalunite alteration but are not filled by either, with only 
Figure 2. Back-scattered electron (BSE) images. A: A large orthopyroxene crystal that has been partially altered to $\mathrm{SiO}_{2}$. Sample T-18-11-07-R8. B: A thin gypsum-filled fracture cutting an area of fine-grained natroalunite. Thin open fractures cut small pseudomorphed crystals. Sample T-15-04-18-R1. C: A vesicle partially filled by generations of $\mathrm{SiO}_{2}$ and natroalunite seen as bands moving towards the center of the vesicle, all cut by younger open fractures. Sample T-18-11-07-R9. D: Continuous gypsum veins cutting a natroalunite matrix with discrete gypsum crystals. A pseudomorphed crystal of an unknown original composition now composed of mostly $\mathrm{SiO}_{2}$ is also seen. Sample T-15-04-18-R1. E: Gypsumfilled fractures intersecting gypsum-filled vesicles in a vesicular basalt clast. Sample T-1904-28-R8B. F: A thin vein of gypsum lined with pyrite that has been disseminated into the surrounding natroalunite matrix. Sample T-19-04-28-R8B.

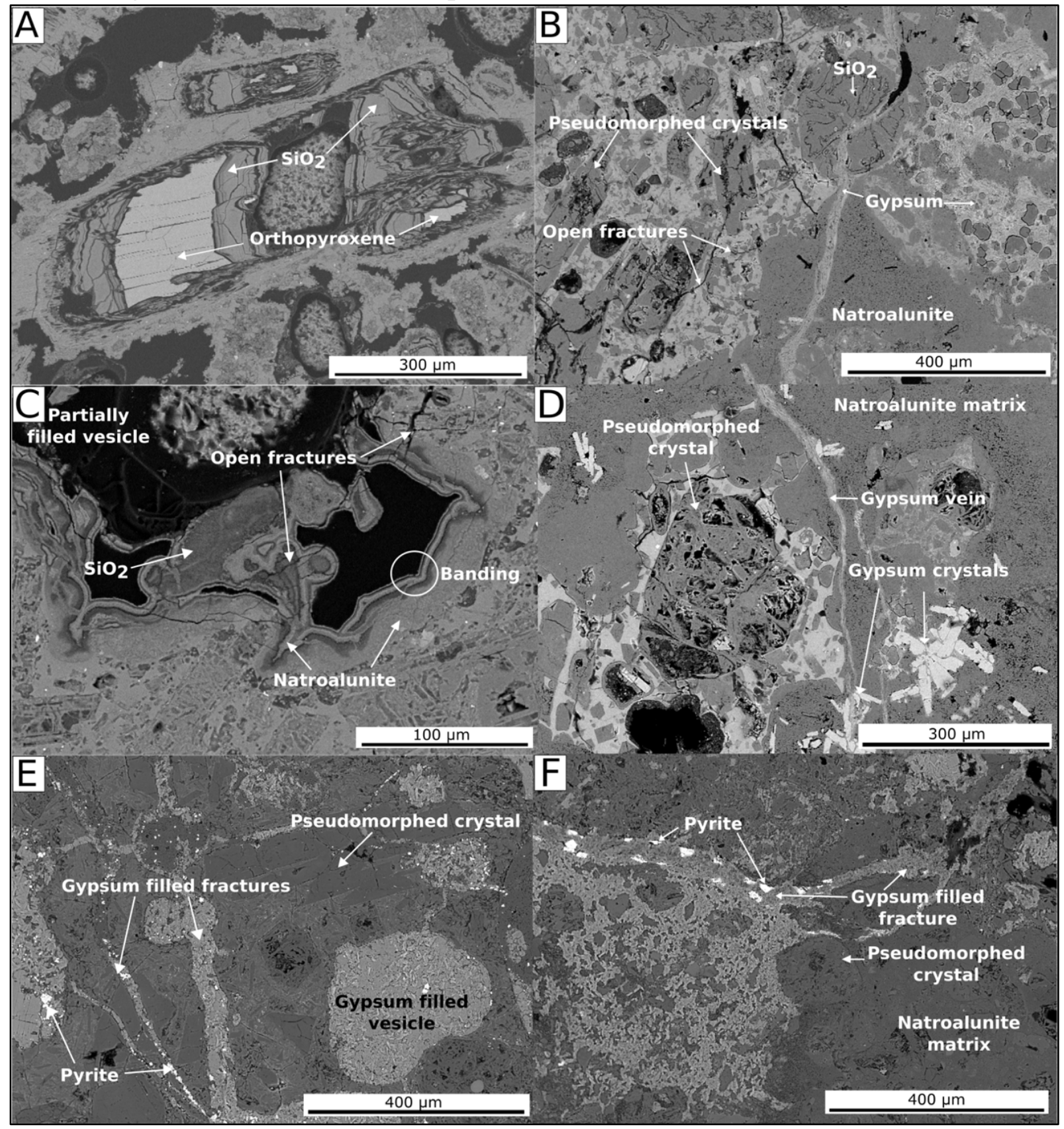


Table 1. Weight percent of matrix mineralogy of pyroclastic breccias determined by XRD. Data reduction was performed using

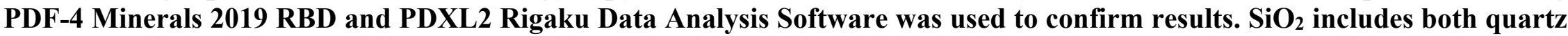
and cristobalite. Natroalunite includes natroalunite-1c, natroalunite-2c, and huangite. Only major minerals were included. All values are approximate and rounded to the nearest $5 \%$. The term "present" denotes values $<5 \%$. Trace minerals including windhoekite, mawsonite, ankerite, $\mathrm{ZnS}$ and $\mathrm{Al}_{2}\left(\mathrm{SO}_{4}\right)_{3}$ were each identified on one occasion with wt $\% \leq 5 \%$ but were omitted due to a lack of certainty associated with their low abundance and low occurrence. Full results including trace minerals and unrounded $w t \%$ available in supplementary data.

\begin{tabular}{|c|c|c|c|c|c|c|c|c|}
\hline Sample Number & Natroalunite & Alunite & Gypsum & Anhydrite & $\mathrm{SiO}_{2}$ & Albite & Anorthite & Pyrite \\
\hline T-15-04-18 R1 & $95 \%$ & & present & & & & & \\
\hline T-15-04-18 R2 & $95 \%$ & & $5 \%$ & & & & & \\
\hline T-16-04-18 R1 & $95 \%$ & & $5 \%$ & & & & & \\
\hline T-16-05-16 R2 & & & & & present & & $100 \%$ & \\
\hline T-18-03-01 R1 & $30 \%$ & & present & & $10 \%$ & $60 \%$ & & \\
\hline T-18-11-07 R8 & $90 \%$ & & & & $10 \%$ & & & \\
\hline T-18-11-07 R9 & & $100 \%$ & & & & & & \\
\hline T-18-11-07 R10 & & & $100 \%$ & & & & & \\
\hline T-18-11-07 R11 & & $65 \%$ & $25 \%$ & & $5 \%$ & & & $5 \%$ \\
\hline T-19-04-28 R2 & & & & & & & $100 \%$ & \\
\hline T-19-04-28 R3 & $80 \%$ & & $5 \%$ & $10 \%$ & present & & & $5 \%$ \\
\hline T-19-04-28 R4 & & $85 \%$ & & & present & & & $15 \%$ \\
\hline T-19-04-28 R5 & $15 \%$ & & $20 \%$ & & present & $60 \%$ & & \\
\hline T-19-04-28 R6 & $85 \%$ & & $10 \%$ & & $5 \%$ & & & \\
\hline T-19-04-28 R7 & $80 \%$ & & $5 \%$ & & present & & & $15 \%$ \\
\hline T-19-04-28 R8 & $75 \%$ & & $20 \%$ & & & & & $5 \%$ \\
\hline T-19-04-28 R9 & $100 \%$ & & present & & & & & \\
\hline T-19-04-28 R10 & $80 \%$ & & $10 \%$ & & $10 \%$ & & & \\
\hline T-19-04-28 R11 & $20 \%$ & & $10 \%$ & & present & $70 \%$ & & \\
\hline
\end{tabular}


Table 2. Alteration assemblage and original mineralogy for pyroclastic breccia samples determined using $\mathrm{SEM}^{\mathrm{SiO}} \mathrm{includes}_{2}$ both quartz and cristobalite.

\begin{tabular}{|c|c|c|c|c|c|c|c|}
\hline \multirow{2}{*}{$\begin{array}{l}\text { Sample } \\
\text { Number }\end{array}$} & \multicolumn{4}{|c|}{ Alteration Assemblage } & \multicolumn{3}{|c|}{ Original Mineralogy } \\
\hline & $\mathrm{SiO}_{2}$ & Gypsum & Natroalunite & Pyrite & Clinopyroxene & Orthopyroxene & Plagioclase \\
\hline T-15-04-18-R1 & $\checkmark$ & $\checkmark$ & $\checkmark$ & & & & \\
\hline T-15-04-18-R2 & $\checkmark$ & $\checkmark$ & $\checkmark$ & & $\checkmark$ & & \\
\hline T-16-04-18-R1 & $\checkmark$ & $\checkmark$ & $\checkmark$ & & & & \\
\hline $\mathrm{T}-16-05-16-\mathrm{R} 2$ & $\checkmark$ & & & & $\checkmark$ & & \\
\hline T-18-03-01-R1 & $\checkmark$ & & & & & & \\
\hline T-18-11-07-R8 & $\checkmark$ & & & & & $\checkmark$ & \\
\hline T-18-11-07-R9 & $\checkmark$ & $\checkmark$ & $\checkmark$ & $\checkmark$ & & & \\
\hline T-18-11-07-R10 & $\checkmark$ & $\checkmark$ & $\checkmark$ & & $\checkmark$ & & \\
\hline T-18-11-07-R11 & $\checkmark$ & $\checkmark$ & $\checkmark$ & & & & \\
\hline T-19-04-28-R3 & $\checkmark$ & $\checkmark$ & $\checkmark$ & & $\checkmark$ & $\checkmark$ & \\
\hline T-19-04-28-R4 & $\checkmark$ & & & $\checkmark$ & $\checkmark$ & $\checkmark$ & \\
\hline T-19-04-28-R5 & $\checkmark$ & $\checkmark$ & & $\checkmark$ & $\checkmark$ & & $\checkmark$ \\
\hline T-19-04-28-R7 & $\checkmark$ & $\checkmark$ & & $\checkmark$ & $\checkmark$ & & $\checkmark$ \\
\hline T-19-04-28-R8 & $\checkmark$ & $\checkmark$ & $\checkmark$ & $\checkmark$ & & & \\
\hline
\end{tabular}


gypsum filling these fractures. The presence of large open fractures is suggestive of late-stage fracturing after the two stages of replacement, possibly caused by the eruption of the breccia.

\subsubsection{Physical Properties}

Permeability and porosity were measured for two fresh scoria samples (T-19-04-28-R1 and T-19-04-28-R12) and a subset of eleven pyroclastic breccias. A minimum core diameter and length of $2.54 \mathrm{~cm}$ was necessary for analysis, so some samples were not analyzed due to insufficient size. However, little variation was seen with regards to porosity and permeability of the tested samples, so we assume that the omitted samples have permeability and porosity values in the ranges below.

Porosity measurements at atmospheric conditions varied from $4.47 \%$ to $27.5 \%$ for pyroclastic breccias and from $53.3 \%$ to $54.7 \%$ for fresh scoria samples (Table 3). At 500 psi porosity varied from $1.99 \%$ to $35.2 \%$ for pyroclastic breccias, and from $52.7 \%$ to $55.0 \%$ for fresh scoria samples (Table 3, Figure 3a). Porosity values are highly dependent on clast composition. At both atmospheric conditions and 500 psi, sample T-19-04-28-R2 was a clear outlier with significantly higher porosity than all other breccia samples (Figure 3a). This sample is a clastdominated breccia with exclusively vesicular basalt clasts. Samples with a higher percentage of vesicular clasts overall tended to have higher porosities. The porosity of any given sample varies no more than $3.26 \%$ between atmospheric conditions and 500 psi, again with the exception of sample T-19-04-28-R2 which has a difference of $7.72 \%$. No porosity trends with respect to alteration were discernible.

Permeability values for gases varied from $<0.001 \mathrm{mD}$ to $10.6 \mathrm{mD}$ for pyroclastic breccias and from $38.7 \mathrm{mD}$ to $55.4 \mathrm{mD}$ for fresh scoria samples (Table 3). Permeability values for liquids varied from $<0.001 \mathrm{mD}$ to $7.68 \mathrm{mD}$ for pyroclastic breccias and from $30.7 \mathrm{mD}$ to $44.9 \mathrm{mD}$ for 
fresh scoria samples (Table 3, Figure 3). As with porosity, sample T-19-04-28-R2 was an outlier with significantly higher permeability than all other breccia samples, $10.6 \mathrm{mD}$ for gases and 7.68 $\mathrm{mD}$ for liquids. With the exception of this sample, all breccias had permeabilities below $1.74 \mathrm{mD}$ for gasses and $0.99 \mathrm{mD}$ for liquids.

Density values for pyroclastic breccia samples varied from $1685 \mathrm{~kg} / \mathrm{m}^{3}$ to $2323 \mathrm{~kg} / \mathrm{m}^{3}$ and from $1242 \mathrm{~kg} / \mathrm{m}^{3}$ to $1302 \mathrm{~kg} / \mathrm{m}^{3}$ for fresh scoria samples (Table 3, Figure 3b). In all cases, the measured densities of the altered pyroclastic breccias fell below that of an average fresh andesite (2400 kg/m³; Heap and Kennedy, 2016).

Given that pyroclastic breccias originate within a volcanic vent, they will generally undergo some degree of alteration. It is therefore difficult, if not impossible, to obtain an unaltered sample, and thus analogues are required. Fuller and Sharp (1993) conducted permeability measurements on fresh, altered and varnished samples of the Santana Tuff in Trans-Pecos Texas and obtained mean permeabilities of $55.33 \mathrm{mD}, 5.03 \mathrm{mD}$ and $3.31 \mathrm{mD}$ respectively. This tuff varies in lithic composition and welding, hence it is not an exact analogue for an unaltered pyroclastic breccia. However, it does provide a range of permeability for explosive volcanic rocks. Heap et al. (2017) conducted permeability measurements on an assortment of minimally altered lava and variably altered lava breccia samples from White Island, New Zealand, another active andesitic stratovolcano. They found the lavas to have permeabilities of $1.80-11.25 \mathrm{mD}$, while lava breccias had permeabilities of 100.62-138.81 mD. Given the similarities between White Island and Turrialba, these lavas and lava breccias provide a reasonable proxy for the fresh equivalent of the pyroclastic breccias studied here. With this information, a significant loss of permeability through alteration is clear. As with porosity, however, no temporal trends with respect to alteration are discernible. 
Figure 3. A: Porosity (\%) at 500 psi as a function of gas permeability (mD). B: Bulk density $\left(\mathrm{kg} / \mathrm{m}^{3}\right)$ as a function of gas permeability $(\mathrm{mD})$.
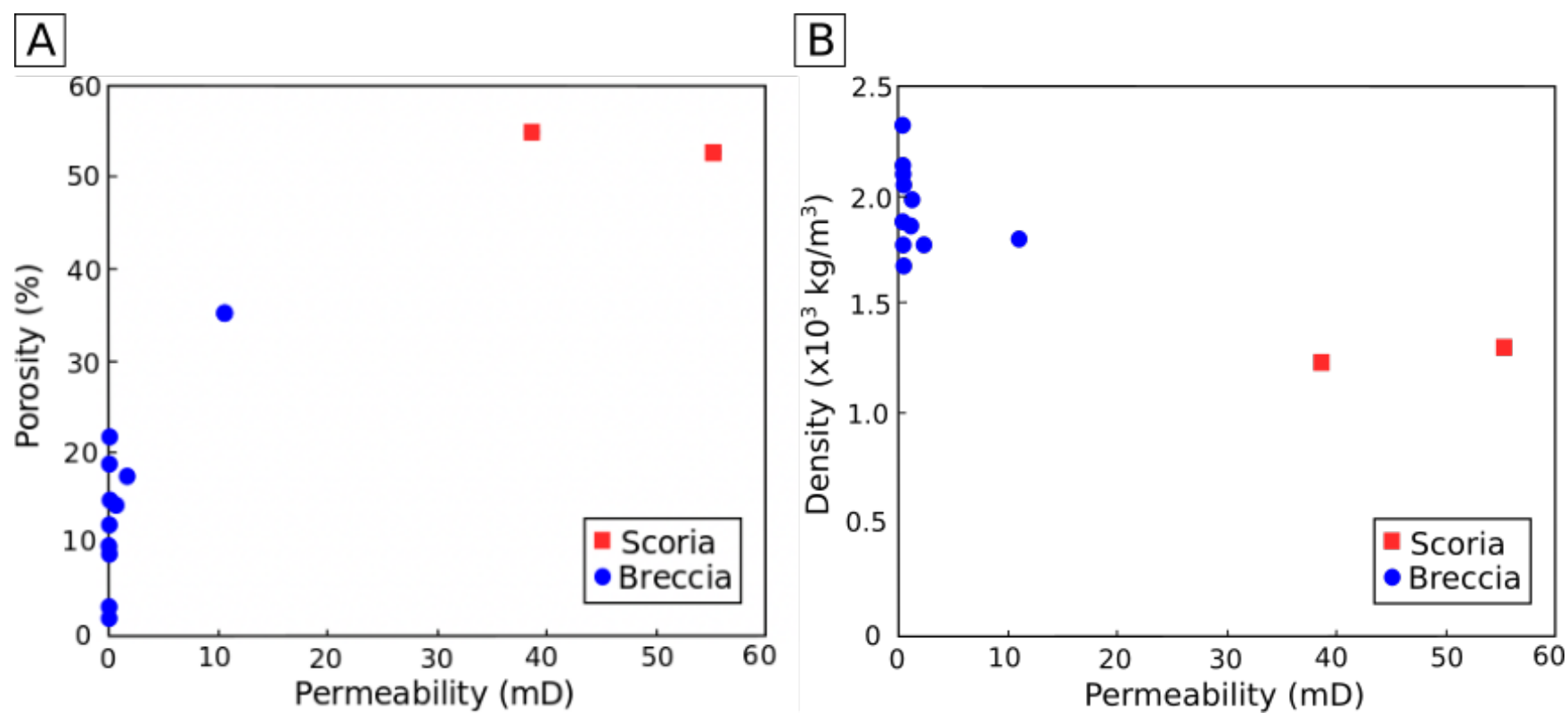

Table 3. Physical properties of selected hydrothermal breccias and fresh scoria samples ( $T$ 19-04-28-R1 and T-19-04-28-R12). Porosity at room temperature determined by grain volume. Porosity at 500 psi and gas permeability determined by a combined gas permeameter/porosimeter. Liquid permeability determined using a Klinkenberg correction.

\begin{tabular}{|c|c|c|c|c|c|}
\hline $\begin{array}{l}\text { Sample } \\
\text { Number }\end{array}$ & $\begin{array}{c}\text { Density } \\
\text { (Bulk) }\end{array}$ & $\begin{array}{r}\text { Porosity } \\
\text { (Room) }\end{array}$ & $\begin{array}{l}\text { Porosity } \\
(500 \text { psi) }\end{array}$ & $\begin{array}{c}\text { Permeability } \\
\text { (Gas) }\end{array}$ & $\begin{array}{c}\text { Permeability } \\
\text { (Liquid) }\end{array}$ \\
\hline & $\mathrm{kg} / \mathrm{m}^{3}$ & $\%$ & $\%$ & $\mathrm{mD}$ & $\mathrm{mD}$ \\
\hline $\mathrm{T}-15-04-18-\mathrm{R} 1$ & 1990 & 13.7 & 14.3 & 0.87 & 0.44 \\
\hline $\mathrm{T}-15-04-18-\mathrm{R} 2$ & 2038 & 4.47 & 1.99 & $<0.001$ & $<0.001$ \\
\hline T-19-04-28-R1 & 1242 & 54.7 & 55.0 & 38.7 & 30.7 \\
\hline T-19-04-28-R2 & 1806 & 27.5 & 35.2 & 10.6 & 7.68 \\
\hline T-19-04-28-R3 & 1764 & 19.7 & 17.3 & 1.74 & 0.99 \\
\hline T-19-04-28-R5 & 1867 & 14.4 & 14.7 & 0.40 & 0.16 \\
\hline T-19-04-28-R6 & 1685 & 18.0 & 18.8 & $<0.001$ & $<0.001$ \\
\hline T-19-04-28-R7 & 1878 & 14.7 & 12.2 & $<0.001$ & $<0.001$ \\
\hline T-19-04-28-R8 & 2060 & 9.93 & 9.82 & $<0.001$ & $<0.001$ \\
\hline T-19-04-28-R9 & 1770 & 18.7 & 21.8 & $<0.001$ & $<0.001$ \\
\hline T-19-04-28-R10 & 2075 & 8.51 & 9.00 & $<0.001$ & $<0.001$ \\
\hline T-19-04-28-R11 & 2323 & 6.58 & 3.32 & $<0.001$ & $<0.001$ \\
\hline T-19-04-28-R12 & 1302 & 53.3 & 52.7 & 55.4 & 44.9 \\
\hline
\end{tabular}




\subsubsection{Fracturing}

Fractures were analyzed qualitatively and quantitatively for multiple samples. Fracture connectivity was determined by looking at the proportions of the three types of fracture interactions: terminations, abutments and crossings. Results show that abutments, where one fracture ends as it intersects a second usually larger fracture, are the dominant feature within each scale of fracture analyzed (Figure 4). Crossings, where two fractures intersect and both continue, as well as terminations, where a fracture ends, play less important roles. The dominance of abutments over other features is responsible for a general anastomosing character of the fracture networks seen at all scales (Figure 5a, 5b). These observations indicate a high degree of connectivity.

Three primary scales of fractures are seen: macro-scale fractures with a width $>10 \mu \mathrm{m}$, micro-fractures with a width of $1-10 \mu \mathrm{m}$ and nano-scale fractures with a width $<1 \mu \mathrm{m}$ (Figure $5 \mathrm{~b}$, 5c). Micro-scale fractures appear to be the dominant scale, with nano- and macro-fractures each responsible for a similar but lesser proportion (Figure 6a). Macro- and micro-scale fractures are present in both matrix and clasts, but nano-scale fractures are only visible within clasts either in glass or crystals (Figure 5c, 5d, 5e). Fractures are not restricted by the different media and can continue across clast and crystal boundaries (Figure 5a). Instances of fractures surrounding clasts and crystals have also been noted, but this behavior is uncommon. Large fractures 1-5 $\mathrm{mm}$ in diameter are also visible at the sample scale although they are less common (Figure 5f).

One aspect of fractures that does show variation between matrix and clasts is wall texture. Fractures within the matrix tend to display a rougher, more irregular wall texture, while fractures within clasts and crystals tend to have smooth walls (Figure 5d, 5e). Fracture filling is also variable. As discussed above, fractures are filled with gypsum and occasionally pyrite; this is consistent 
Figure 4. Proportions of terminations, abutments, and crossings illustrate the degree of connectivity among pyroclastic breccia samples. A: General connectivity taking into consideration fractures at all scales. Intersections (abutments and crossings) are present in a higher proportion than terminations, indicating a high degree of connectivity. B: Connectivity features divided into five spatial scales. Intersections (abutments and crossings) are present in a higher proportion than terminations at all scales, demonstrating the general insensitivity of scale. C: Back-scattered electron (BSE) images showing examples of abutments, terminations and crossings.

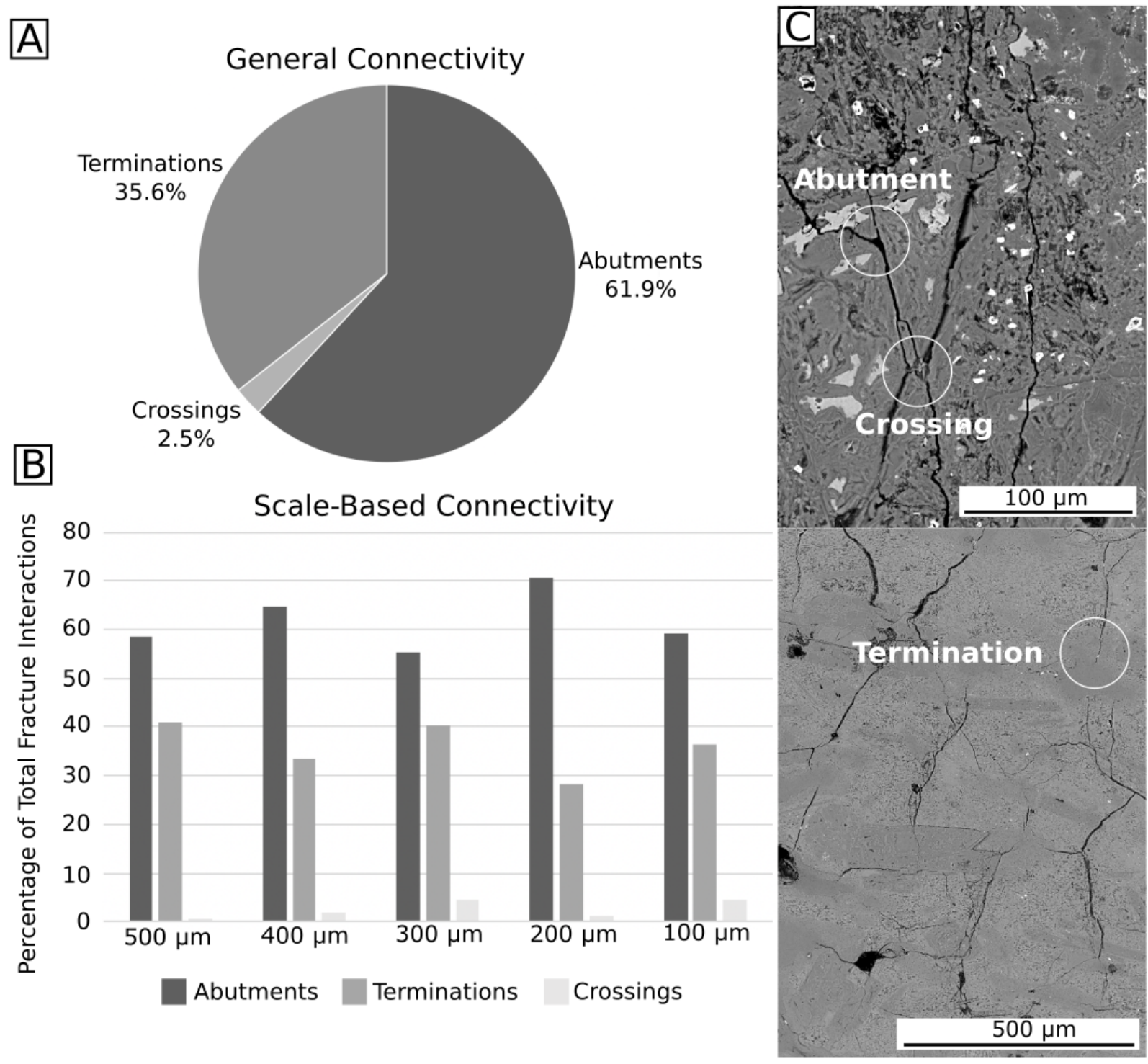


Figure 5. Back-scattered electron (BSE) images. A: Continuous open and anastomosing fractures transecting a pseudomorphed crystal. B: Open macro-fractures and anastomosing micro-fractures. C: Open continuous micro-fractures and nano-fractures within a basalt clast. D: Smooth walled fractures within a basalt clast surrounded by matrix containing rough walled fractures. E: Open, anastomosing, irregular macro-fractures within the matrix. F: Large filled fracture within a pyroclastic breccia sample.

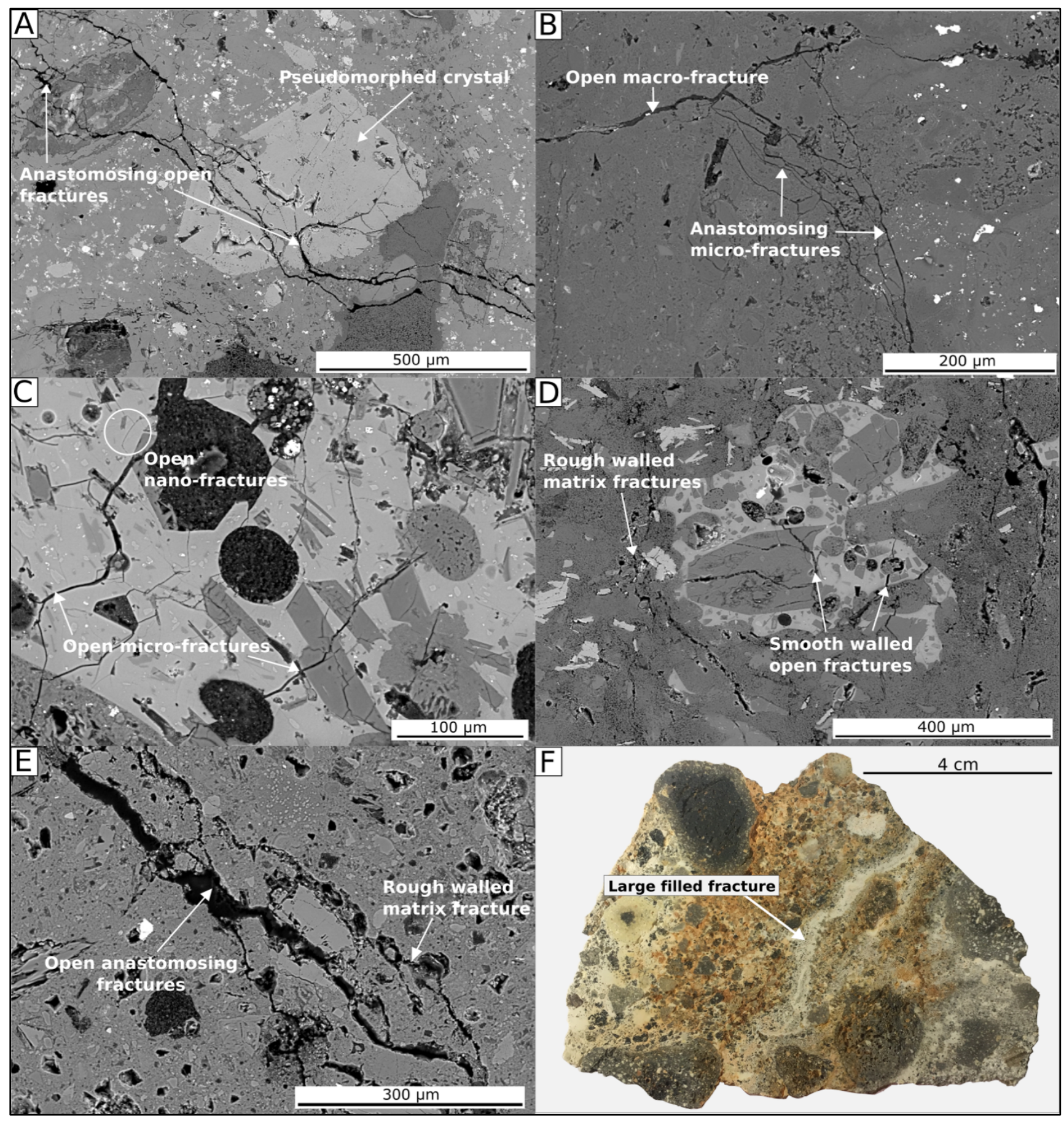


Figure 6. A: Distribution of macro-scale fractures with a width $>10 \mu \mathrm{m}$, micro-fractures with a width of 1-10 $\mu \mathrm{m}$ and nano-scale fractures with a width $<1 \mu \mathrm{m}$. B: Distribution of filled and open fractures within each fracture scale.

A Fracture Scale Distribution

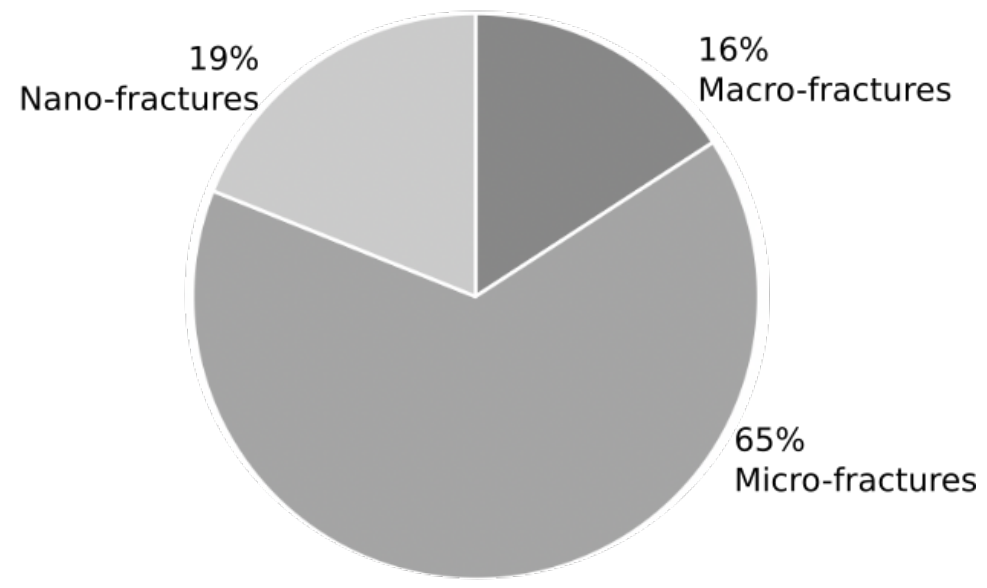

B

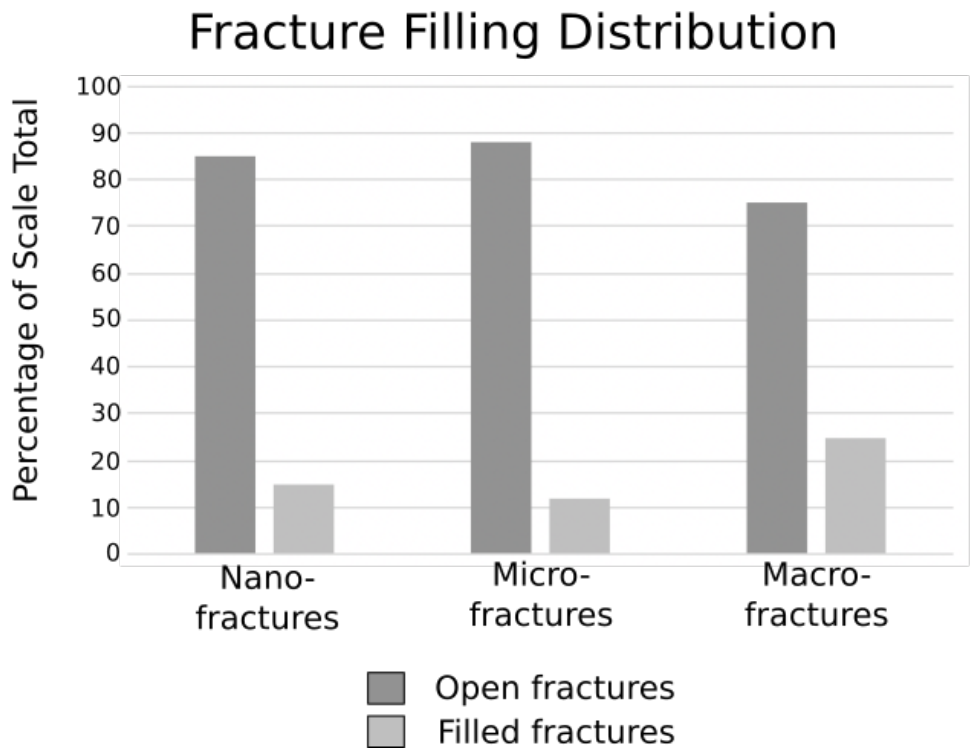

across all samples. However, filling does not occur preferentially in any one media (i.e., matrix, clast or crystal), and open fractures are more prevalent than filled fractures at all scales (Figure 6b). Filled and open fractures are present within all samples, and filling can be discontinuous within a single fracture (Figure 7). It is worth noting that some fragile filling material may have 
been lost during seal rupture or sample processing, hence, proportions of open fractures are maximum values, and those of filled fractures are minimum values.

Connectivity is not a two-dimensional feature, so CT-scanning was used to image the fracture network in three-dimensions. The scans yield a series of images representing vertical slices through a rock core. In the four consecutive slices, each measuring $40 \mu \mathrm{m}$ in thickness seen in Figure 8, a group of fractures is shown to connect over $160 \mu \mathrm{m}$ in thickness. In each image, fractures appear to show several terminations, but in sequence it is clear that an individual fracture continues in the vertical dimension and the terminations may in fact represent a change in fracture orientation. The high degree of three-dimensional connectivity leads us to believe that a significant portion of apparent fracture terminations noted in two dimensions are in fact continuous in the third dimension. The fact that they appear to terminate is the result of a lack of visualization in the third dimension. Hence our connectivity values (Figure 4) are minimums.

Figure 7. Back-scattered electron (BSE) images. In each image, fractures show both open and filled segments. A: Discontinuous filling of a fracture travelling through matrix and clast material. B: Discontinuous filling of a matrix fracture.

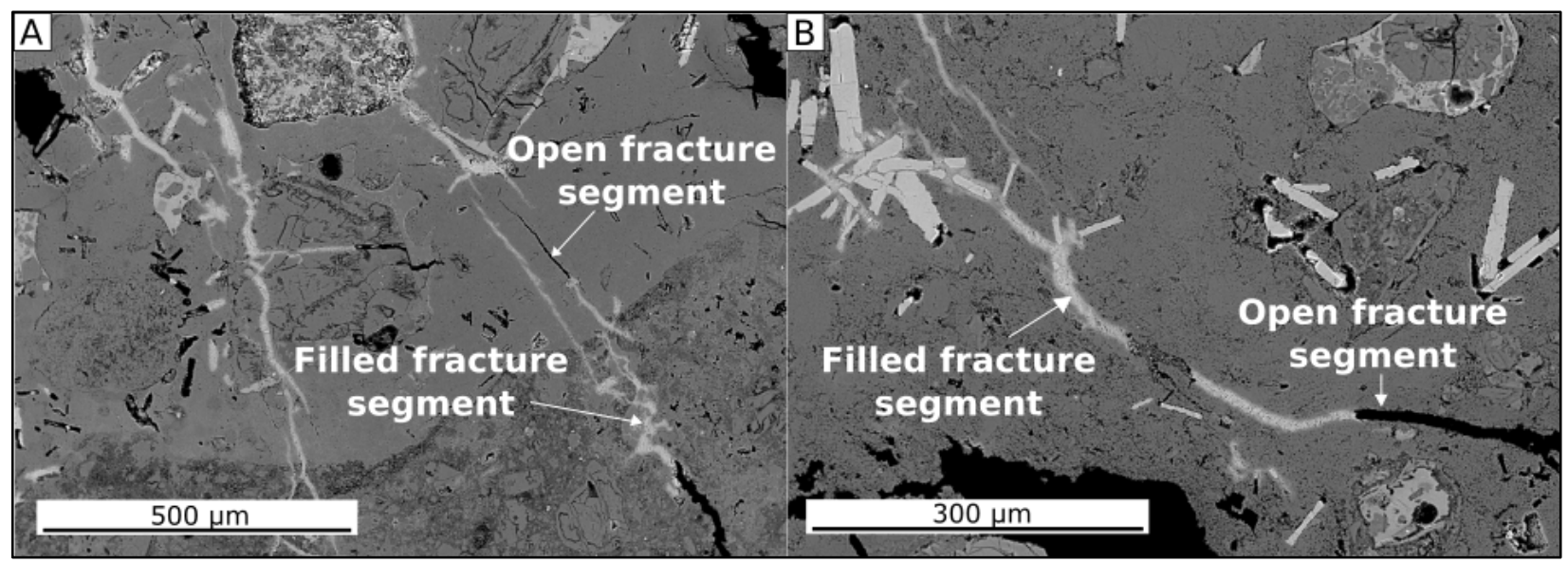


Figure 8. Four consecutive vertical core slices obtained by CT-imaging showing the 3dimensional connectivity of fractures. Each image is separated by a thickness of $40 \mu \mathrm{m}$.

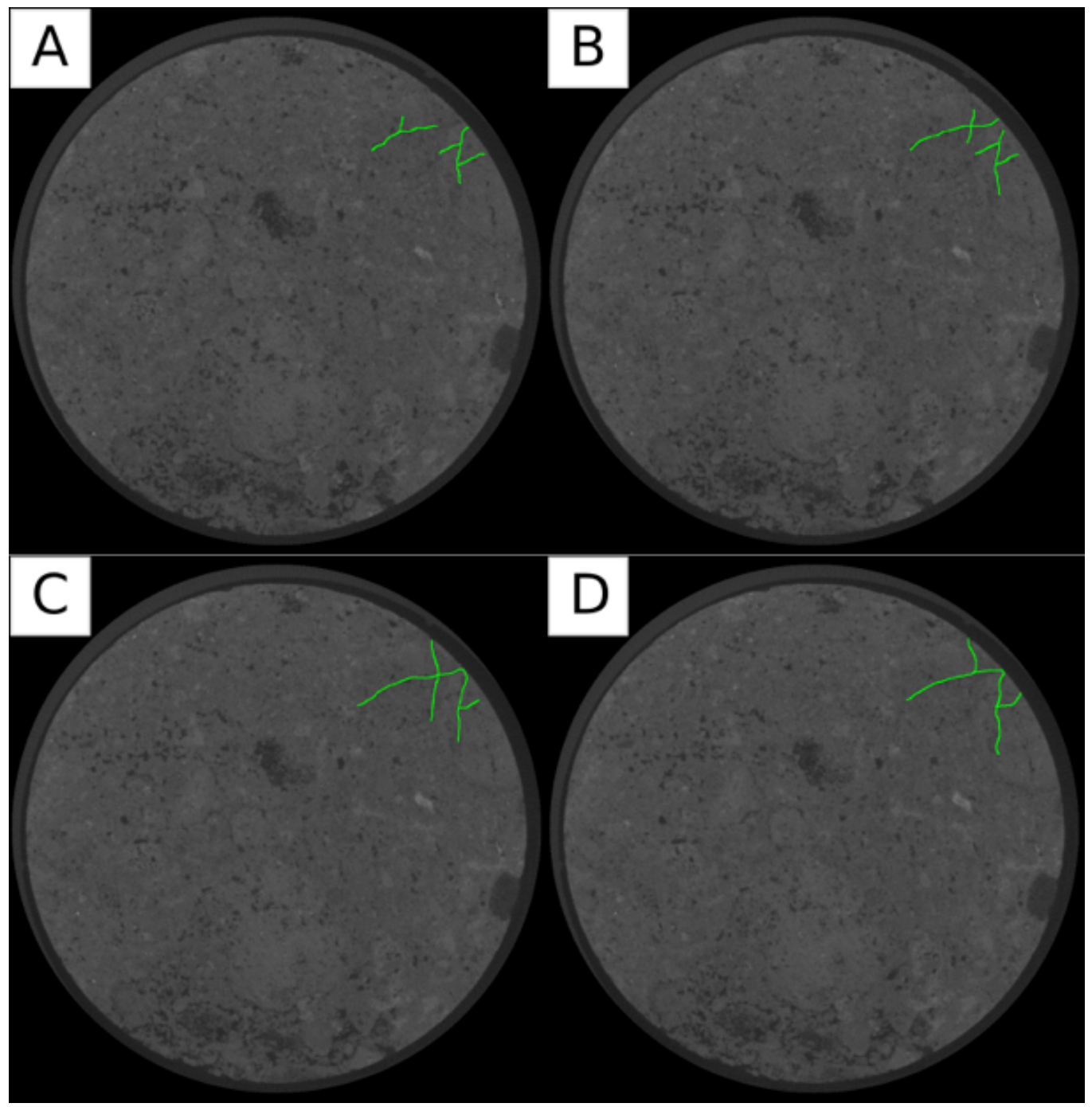

\subsection{Discussion}

Analysis of hydrothermally altered breccias in terms of mineralogy and physical properties has provided new information regarding the mechanism responsible for phreatic eruptions at Turrialba. In the following sections we discuss this evidence and the possible mechanisms for these eruptions and hydrothermal sealing at Turrialba and elsewhere. 


\subsubsection{Examples of Hydrothermal Sealing and Phreatic Eruptions: Ruapehu and Ontake}

Hydrothermal sealing has been studied as the cause of several well-known phreatic or phreatomagmatic eruptions. Here we examine eruptions at two volcanoes, Ruapehu in 2007 and Ontake in 2014. Ruapehu, on the North Island of New Zealand, is an andesitic stratovolcano that has undergone frequent phreatic and phreatomagmatic eruptions throughout the second half of the $20^{\text {th }}$ century (Christenson and Wood, 1993). In 2007 Ruapehu experienced a small phreatomagmatic eruption without warning, resulting in ejecta traveling as far as $2.5 \mathrm{~km}$ from the crater (Christenson et al., 2010). Ruapehu hosts a crater lake known to undergo thermal cycling between $10^{\circ} \mathrm{C}$ and $60^{\circ} \mathrm{C}$ over periods of 4 to 16 months (Christenson et al., 2010). Eruptions at Ruapehu tend to occur during periods of high heat flow and elevated lake temperatures. At the time of the eruption of the September $25^{\text {th }}, 2007$, however, the lake temperature was only $13^{\circ} \mathrm{C}$ (Christenson and Wood, 1993; Kilgour et al, 2010). The event consisted of a block and ash eruption accompanied by a surtseyan jet and several lahars, aided by the fact that the crater lake was already at overflow levels (Kilgour et al, 2010). In the 10 minutes prior to the onset of eruptive activity, a small volcano-tectonic earthquake (VT), a very long period (VLP) event and a burst of tremors were recorded, but this was insufficient warning to enact adequate protection measures (Mordret et al, 2010; Christenson et al., 2010). Within the erupted material, highly altered blocks with low permeability were found, indicating that hydrothermal sealing was at least partly responsible for this eruption (Christenson et al., 2010). In addition, very low $\mathrm{SO}_{2}$ fluxes showing a slight increasing trend coupled with a decrease in $\mathrm{CO}_{2}$ at a time when sulphur was actively being scrubbed from the system indicated the formation of a sulphur seal at a shallow level. An increase in gas emissions and $\mathrm{CO}_{2}$ enrichment of the gases for the three days following the eruption also support the presence of a seal (Christenson et al., 2010). Following the initial period of high $\mathrm{CO}_{2}$ 
after the eruption, a change towards high $\mathrm{SO}_{2} / \mathrm{CO}_{2}$ indicated that the system had transitioned into a magmatic stage of activity (Christenson et al., 2010).

Recent activity at Mount Ontake in central Japan began in 1979, and since then three eruptions have occurred in 1991, 2007 and 2014 (Kaneko et al., 2016). On September 27 $7^{\text {th }}, 2014$ Ontake erupted suddenly with little to no warning resulting in the deaths of 60 people hiking in the area (Kaneko et al., 2016). The 2014 eruption was characterized by a plume reaching $7.8 \mathrm{~km}$ above the crater and eruptive material composed primarily of altered non-juvenile material with a small juvenile component (Oikawa et al., 2016; Miyagi et al., 2020). Hence the eruption was phreatomagmatic rather than phreatic. Hydrothermal minerals including sulphates (gypsum, alunite, anhydrite), clays (kaolin minerals) and cristobalite were all present in the ejecta (Ikehata and Maruoka, 2016). As is common with phreatic eruptions caused by sealing, very little warning preceded this eruption. Workers located in huts on the mountain noted that no rumbling, ground motion or sulphur smell were present prior to the eruption (Oikawa et al., 2016). However, an increase in seismicity was noted in early September 2014 but subsided after September $16^{\text {th }}$ (Kato et al., 2015). Increased seismicity was not observed again until volcanic tremors began 11 minutes prior to the eruption, followed by a rapid inflation of the edifice and laterally migrating VT earthquakes (Kaneko et al., 2016; Kato et al., 2015). The migrating VT earthquakes and inflation are believed to result from rapid movement of pressurized fluids through the conduit, which taken together with the ejecta composition indicate that hydrothermal sealing was a factor in this eruption (Kato et al., 2015). The actual seal rupture is believed to be responsible for the first, less explosive gas phase of the eruption, while the sudden decompression that followed caused rapid boiling of water and a second more explosive phase of activity responsible for most ejecta (Kaneko et al., 2016). Following the eruption, a sustained $\mathrm{SO}_{2}$ flux of $>100 \mathrm{t} /$ day in addition to elevated $\mathrm{SO}_{2} / \mathrm{H}_{2} \mathrm{~S}$ 
was taken to indicate a sustained magmatic fluid supply into the hydrothermal system (Mori et al., 2016).

These two examples show several important similarities. (1) Little to no warning occurred prior to either eruption. The unpredictable nature of phreatic and phreatomagmatic events, in particular those related to hydrothermal sealing, is responsible for the fact that these eruptions are among the most dangerous, Ruapehu and Ontake included. While both volcanoes did exhibit some seismic warning signals, they were limited to several minutes prior to the eruptions, and other common warning signals were absent. At Ruapehu the eruption was unexpected given the low lake temperatures contrary to previous eruptions. (2) Ejecta from both eruptions display a high degree of alteration dominated by hydrothermal minerals including sulphates, clays and silica resulting in low permeability of the ejecta. (3) Eruptive products from both systems were dominantly lithic and altered, while a small juvenile component was also recognized. Hence both eruptions were phreatomagmatic, not phreatic. (4) Following the eruption at Ruapehu, changes in the gas composition and rate of degassing were typical of a seal that had broken, namely an increase in $\mathrm{SO}_{2}$ and $\mathrm{CO}_{2}$ gas emissions and magmatic $\mathrm{SO}_{2} / \mathrm{CO}_{2}$ signatures of the gases. Similarly, $\mathrm{SO}_{2}$ fluxes and $\mathrm{SO}_{2} / \mathrm{H}_{2} \mathrm{~S}$ ratios at Ontake reflected magmatic fluid contributions after eruption. For both systems, the eruptions appear to have opened the plumbing system for a period of time, allowing magmatic gases to move through and exit the volcano.

\subsubsection{Hydrothermal Alteration at Turrialba}

The alteration mineral assemblage at Turrialba consists of $\mathrm{SiO}_{2}$ polymorphs \pm gypsum \pm natroalunite \pm pyrite indicative of acid sulphate alteration (Table 1, Table 2; Armstrong, 1995; Zimbelman et al., 2005). Acid sulphate alteration is common at volcanoes worldwide and is 
characterized by acidic fluids resulting in extreme leaching followed by precipitation of primarily sulphate and sulphide minerals (Armstrong, 1995; Heap et al., 2019). A source of sulphur is an essential component of acid sulphate alteration. In andesitic stratovolcanoes such as Turrialba, isotopic data indicate that sulphate and sulphide alteration minerals are the result of the disproportionation of magmatic $\mathrm{SO}_{2}$ to form the aqueous sulphate required for alteration (Meyer and Hemley 1967; Zimbelman et al., 2005). The near-surface oxidation of $\mathrm{H}_{2} \mathrm{~S}$ may provide a secondary source of sulphate (Stoffregen, 1987).

The alteration mineralogy is indicative of a pre-alteration mineral assemblage consisting of feldspar and pyroxene (Minami et al., 2016). Alunite is typically the product of alkali feldspar leaching, but the dominance of natroalunite containing $\mathrm{Ca}$ and $\mathrm{Na}$ rather than $\mathrm{K}$ indicates that plagioclase is the dominant feldspar phase at Turrialba (Armstrong, 1995). The preserved primary igneous minerals include plagioclase, orthopyroxene and clinopyroxene (Reagan et al., 2006; Table 2).

Acid-sulphate alteration also falls within the field of advanced argillic alteration which is characterized by extreme leaching of cations other than $\mathrm{Al}$ and Si followed by sulphate and sulphide deposition, including but not limited to alunite group minerals, secondary silica, gypsum and pyrite (Meyer and Hemley 1967; Stoffregen 1987; Henley and Berger, 2011; Minami et al., 2016). The assemblage seen at Turrialba is typical of this type of alteration, with the exception of the lack of clay minerals, kaolinite being the most common in such settings. During advanced argillic alteration, alunite group minerals can substitute for clays; given the proper ion availability from feldspars, alunite and natroalunite can form from the reaction of kaolinite with aqueous sulphate, $\mathrm{H}^{+}$and $\mathrm{K}^{+}$(Stoffregen et al., 2000; Henley and Berger, 2011). Plagioclase is an important component of the primary igneous mineralogy, although it has now been largely replaced by $\mathrm{SiO}_{2}$, 
and $\mathrm{SO}_{2}$ is known to be abundant at Turrialba accounting for the dominance of natroalunite and the lack of clay minerals (Vaselli et al., 2010). Kaolinite is not present in any of our samples indicating that temperatures are likely higher than $200^{\circ} \mathrm{C}$ at which point kaolinite is no longer stable (John et al., 2008). Alteration in systems such as Turrialba occurs in zones (e.g., Minami et al., 2016), with advanced argillic/acid-sulphate alteration occupying most of the central area. It is possible that the alteration has produced clays such as kaolinite in areas further from the vent where sulphate is less abundant and temperatures are cooler. However, the breccias analyzed here are sourced directly from the vent area and have therefore exposed to the most $\mathrm{SO}_{2}$-enriched gases and the highest temperatures (John et al., 2008).

The alteration mineral assemblage is consistent for all samples. With the exception of pyrite which as noted above is only present in later samples, no time-based variations in mineralogy are seen. Given that pyrite is not present in all later samples but rather in only a select few, this is likely due to sampling bias rather than a change in chemistry, as more samples were collected following later eruptions (Table 1, Table 2). In addition, pyrite is the least abundant major mineral and therefore could be missing in some samples. The consistent alteration indicates that the magmatic-hydrothermal system at Turrialba has not undergone any major changes between 2014 and 2019 and is likely still in the third phase of activity since reactivation, as described by Vaselli et al. (2010) and Martini et al. (2010), with a dominance of magmatic contributions over hydrothermal contributions.

Given the alteration mineralogy, it is possible to make estimates with respect to the fluids responsible for the alteration. Acid-sulphate alteration is the product of extreme leaching by acidic fluids. The $\mathrm{pH}$ of these fluids can vary but is typically less than 4 as indicated by the presence of natroalunite (Rodriguez and van Bergen, 2017). Most minerals within the assemblage are stable 
across a very wide range of temperatures, hence the temperature of alteration is difficult to constrain. Alunite group minerals including natroalunite are typically associated with temperatures of $200-350^{\circ} \mathrm{C}$ but are stable to temperatures upwards of $380-450^{\circ} \mathrm{C}$ (Meyer and Hemley 1967 ; Henley and Berger, 2011; Heap et al, 2019). Gypsum and its hemi-hydrated form bassenite are stable at temperatures of $<50^{\circ} \mathrm{C}$ to upwards of $200^{\circ} \mathrm{C}$ at high pressure (Klimchouk, 1996). Based on the alteration, we propose that the fluids at Turrialba have $\mathrm{pH}<4$ and temperatures between 200$350^{\circ} \mathrm{C}$. As noted in the mineral paragenesis, it appears that alteration has occurred in two separate stages. A first stage consisting of the deposition of $\mathrm{SiO}_{2}$ and natroalunite was followed by the deposition of gypsum in a later stage of alteration. We believe this is the result of the differing temperature requirements of the minerals. Natroalunite and $\mathrm{SiO}_{2}$ would have been deposited first at high temperature, beginning the sealing process and allowing pressure to build. A second, lowertemperature stage then allowed for the deposition of gypsum, causing further sealing. Similar alteration at Merapi volcano was found to be the result of fluids with a $\mathrm{pH}<3$ and temperatures $>200^{\circ} \mathrm{C}$ (Heap et al, 2019). Conditions corresponding with advanced argillic and therefore acidsulphate alteration are believed to occur between the surface and $2 \mathrm{~km}$ depth (Minami et al., 2016). It is known that Turrialba hosts a shallow hydrothermal system and a magma reservoir as shallow as $1 \mathrm{~km}$ below the surface (Di Piazza et al., 2015; Rizzo et al., 2016). Hence, we propose that this alteration occurred within the uppermost kilometer of the system.

A potential additional stage of alteration exists in the form of post-eruptive alteration. All samples analyzed herein were collected from the crater of Turrialba in the weeks to months following their eruption. Given the high level of activity at Turrialba, these samples will in all likelihood have been exposed to high levels of volcanic gases. Some samples feature surficial finegrained native sulphur, but this alteration is limited to the exposed surface of the sample. Exposure 
at the surface may also have resulted in the dehydration of anhydrite to gypsum; however, no replacement textures were noted with respect to the gypsum replacing anhydrite.

\subsubsection{Permeability and Fracturing}

Permeability and porosity are important factors in hydrothermal sealing as they control the movement of fluids and gases through a rock. Hydrothermal alteration can both increase and decrease permeability and porosity through mineral breakdown and mineral replacement respectively (Mordensky et al., 2019b). We determined above that lava and lava breccia samples from White Island, New Zealand, analyzed by Heap et al. (2017) could be used as an analogue for unaltered pyroclastic breccia samples. They found the lavas to have permeabilities of 1.80-11.25 $\mathrm{mD}$, while lava breccias had permeabilities of 100.62-138.81 mD. With the exception of sample T-19-04-28-R2, a vesicular basalt clast-dominated breccia, no permeability values of pyroclastic breccias at Turrialba exceed the lowest fresh estimate of $1.80 \mathrm{mD}$. This indicates that precipitation has dominated over dissolution, and hydrothermal alteration of the breccia samples has caused a reduction in permeability. Previous studies have found that hydrothermal alteration can lower the permeability of samples by up to four orders of magnitude which is consistent with our findings (Heap et al., 2017; Heap et al., 2019; Farquharson et al., 2019). The processes of dissolution and precipitation are both likely to be occurring within the system, but the balance between them may vary. Given the high degree of replacement seen within most mineral grains (Figure 2b, 2d) we propose that a period dominated by dissolution likely preceded the precipitation that resulted in a loss of permeability.

Some samples display very low permeability values but relatively high porosity values. For example, sample T-19-04-28-R9 has a permeability of $<0.001 \mathrm{mD}$ but porosity values of 18.7- 
21.8\% (Table 3). Discrepancies between permeability and porosity values are likely due to fractures being responsible for only a certain portion of the overall porosity, meaning a large decrease in permeability due to fracture filling would have a relatively small effect on porosity (Heap et al., 2019; Farquharson et al., 2019).

Permeability, however, is not simply a factor of porosity; it is influenced by fracture connectivity (Heap et al., 2017). As shown in Figure 5, the breccia samples host complex networks of nano-, micro- and macro-scale fractures that are variably filled with hydrothermal minerals. Well-connected fracture networks as seen here are typical of moderate to high porosity volcanic rocks (Heap and Kennedy, 2016). Our analysis of connectivity demonstrates that breccias from Turrialba display a high degree of connectivity among both filled and open fractures (Figure 4). This connectivity is supported by the lack of variation within permeability and porosity values (Table 3, Figure 3). The high degree of connectivity among fractures is indicative of moderate permeability, yet our measured values indicate that the breccia samples have a very low permeability, supporting the conclusion that hydrothermal alteration has resulted in an important loss of permeability. This poses a paradox since a majority of fractures at all scales are open rather than filled (Figure 6b). As shown previously, however, filling is frequently observed to be discontinuous (Figure 7a, 7b). As a result of this discontinuous hydrothermal filling, a significant portion of fractures that appear "open" are in fact blocked by filling elsewhere in the fracture network and therefore do not contribute to the overall permeability. Additionally, a portion of fractures were likely the result of the eruption process and therefore will not have been subjected to fracture filling.

Fracturing does not appear to occur preferentially in one media, but the media type does nonetheless affect the nature of the fracturing and therefore permeability. For example, fractures 
within the matrix display a rough, irregular wall texture in comparison to fractures within clasts and crystals (Figure 5d,5e). This is due to the granular nature of the matrix as compared to the fine-grained glassy nature of the clasts. Due to the disruption of flow, fractures with rough walls tend towards lower permeability (Heap and Kennedy, 2016). Therefore, the abundance of matrix within a sample and the distribution of fractures between the matrix and clasts will impact permeability. Additionally, nano-scale fractures were only found within crystals and clasts (Figure 5c). This is again believed to be due to the fine-grained glassy nature of the media, but as these fractures tend to be discontinuous, their effect on permeability would be limited. However, their presence does affect the overall connectivity.

As noted above, fracturing appears to have occurred in several stages rather than as a singular event. It is not possible to discern the precise number of stages and the causes of each stage, but several causes have likely played a role. Firstly, as discussed above, a portion of the fractures are likely the result of the phreatic eruptions that produced the breccia samples. The pressure and energy associated with seal rupturing and the ensuing phreatic eruptions result in large-scale fractures that open the vent and can also form the small-scale fractures seen within all samples. Secondly fracturing may be the result of seismic activity. Many seismic swarms have been associated with the reactivation of Turrialba, in addition to ongoing seismic activity common to active volcanoes. Lastly, fractures may be due to an accumulation of pressure either within the hydrothermal system or from an accumulation of magmatic gases. All these sources of fractures are recurring within the system and can thus be responsible for multiple generations of filled and open fractures. 


\subsubsection{Hydrothermal Sealing at Turrialba}

Hydrothermal sealing occurs when fluids within the magmatic-hydrothermal system of an active volcano deposit hydrothermal minerals including $\mathrm{SiO}_{2}$ polymorphs, sulphate species and clays within the shallow subsurface of the volcano (upper 1-2 km) including the vent, thus reducing the permeability of the vent material and allowing for gas and pressure buildup. The rocks forming this seal will display a high degree of alteration, host significant hydrothermal mineralization, and display low intrinsic permeability (Christenson et al., 2010). As demonstrated above, the pyroclastic breccia samples collected at Turrialba produced by eruptions in 2014-2019 have been heavily altered by acid-sulphate fluids resulting in an abundance of hydrothermal minerals including $\mathrm{SiO}_{2}$ polymorphs \pm gypsum \pm natroalunite \pm pyrite. Using an analogue for a fresh equivalent, we can also determine that this alteration has resulted in a significant decrease in permeability due to the filling of the complex fracture networks present. Previous work by Heap et al. (2017) found that acid sulphate fluids reduce the permeability of shallow volcanic rocks due to the deposition of alunite-group minerals, supporting our finding that the reduction in permeability at Turrialba is due to alteration and not another mechanism. We therefore conclude that these pyroclastic breccia samples are samples of multiple failed hydrothermal seals formed at Turrialba since 2014 which are responsible for the frequent phreatic eruptions seen.

Seals may fail due to either chemical or mechanical breakdown. Chemical breakdown of a seal as a result of changes within the magmatic-hydrothermal system will likely allow for the gradual venting of pressure and thus is unlikely to trigger an eruption. Mechanical breakdown of a hydrothermal seal is the result of an accumulation of pressure below the seal until a certain overpressure is reached, resulting in the failure of the rocks forming the seal and the sudden release of pressure. Mechanical breakdown of seals is believed to trigger phreatic eruptions. 
Previous studies of volcanic gases at Turrialba provide additional evidence for hydrothermal sealing. In the weeks prior to the October $29^{\text {th }}, 2014$ eruption, de Moor et al. (2016a) noted that both $\mathrm{SO}_{2}$ and $\mathrm{CO}_{2}$ flux values were very low at Turrialba, indicating the possibility of a seal inhibiting the escape of gas. Following the December $9^{\text {th }}, 2014$ eruption, the same study noted a dramatic increase in gas fluxes immediately following the eruption. Along with erratic preeruptive gas fluxes, a sudden increase in gas flux after a phreatic eruption is strong evidence for the rupture of the hydrothermal seal (Christenson and Tassi, 2015). Such post-eruptive increases have been observed at Ruapehu, Ontake and, Turrialba.

Hydrothermal sealing occurs by degrees, and a complete seal is not necessary in order for phreatic eruptions to be triggered. More complete seals are likely to accumulate gas more quickly, but it is only necessary for the flow of gas into the system from below to exceed the rate of gas escape in order for pressure to accumulate. A near continuous plume of gas present at Turrialba since 2014 may indicate that sealing is only partial (de Moor et al., 2016a). Another important consideration is the strength of the rock forming the seal. A stronger rock will be able to withstand higher pressures before cracking. Therefore, a seal formed within stronger rocks will likely require higher pressures for the seal to fail. This is likely to lead to less frequent but larger eruptions.

The timescale at which sealing is active is also an important feature to consider. The frequent phreatic eruptions at Turrialba since 2010 indicate that sealing is a recurring process and occurs on a relatively short timescale, on the order of months to a year or more. In addition, as this is based on the frequency of seal failure, it is possible that seals are forming on an even shorter timescale, as the rate of gas accumulation as well as the rate of sealing and the strength of the seal will all affect the frequency of seal failure. We propose that sealing could occur on timescales as short as days to weeks when small amounts of hydrothermal minerals cause a rapid reduction in 
permeability of the system. This is suggested by (1) the discontinuous fracture filling (Figure 7) and (2) the irregular, anastomosing network of micro-fractures (Figure 5). Such permeability decreases could quickly drive the system across a sealing threshold, generating the overpressure necessary for seal rupture and eruption. Finally, it is likely that sealing will continue as long as the magmatic-hydrothermal system remains in its current state as described by Vaselli et al. (2010) and Martini et al. (2010).

\subsubsection{Hydrothermal Sealing Model}

Sealing at Turrialba occurs when hot magmatic gases released from the shallow magmatic system (1-10 km from the surface; Di Piazza et al., 2015) below the crater travel upwards, entering and dissolving in the hydrothermal system (Figure 9). The introduction of these magmatic gases results in the formation of acid-sulphate fluids with a $\mathrm{pH}<4$ and temperatures ranging from 200350 ${ }^{\circ} \mathrm{C}$ (Meyer and Hemley 1967; Klimchouk, 1996; Henley and Berger, 2011; Rodriguez and van Bergen, 2017; Heap et al, 2019). The acidic fluids cause the leaching and subsequent deposition of the alteration mineral assemblage $\left(\mathrm{SiO}_{2}\right.$ polymorphs \pm gypsum \pm natroalunite \pm pyrite $)$ within the vent (upper 1-2 $\mathrm{km}$ of the volcano) in a two-stage depositional process. The deposition of alteration minerals within the fracture network causes the gradual restriction of flow within some fractures while fully closing other fractures. The restriction of fractures at key points within the fracture network would result in a reduction in permeability within the vent thus forming a hydrothermal seal. These fractures formed prior to sealing as outlined above. In all likelihood Turrialba hosts only a partial seal. The seal nevertheless allows for the accumulation of hydrothermal and magmatic gases within the vent allowing for an accumulation of pressure until sufficient overpressure is reached. Overpressure will result in the mechanical failure of the seal 
and the formation of additional fractures, ultimately resulting in a phreatic eruption. Further fracturing will occur during the eruption. This process will then recur with timescales based on the rate of degassing and the strength of the seal. Following the rupture of the seal and the ensuing phreatic eruption, the system is likely to remain open for a period of time until hydrothermal deposition begins to close the system anew.

\subsection{Conclusions}

Since its reactivation, Turrialba has experienced frequent phreatic eruptions which are unpredictable and dangerous by nature. We propose that these eruptions are the result of hydrothermal sealing wherein the fluids circulating within the shallow magmatic-hydrothermal system first leach the rocks, then deposit hydrothermal minerals, resulting in a loss of permeability leading to sealing and gas accumulation. Sufficient gas accumulation will in time result in overpressure and eventually failure of the seal triggering eruptions.

A suite of pyroclastic breccias believed to be pieces of failed seals that resulted in phreatic eruptions between 2014 and 2019 have been analyzed for their mineralogy and physical properties. An alteration assemblage of $\mathrm{SiO}_{2}$ polymorphs \pm gypsum \pm natroalunite \pm pyrite was identified for all samples, indicative of acid sulphate alteration within the advanced argillic alteration facies. This alteration is consistent with fluids of $\mathrm{pH}<4$ and of $200-350^{\circ} \mathrm{C}$ (Meyer and Hemley 1967; Klimchouk, 1996; Henley and Berger, 2011; Rodriguez and van Bergen, 2017; Heap et al, 2019). The alteration mineralogy is present within the ash matrix, as replacement of primary igneous minerals, and filling fractures. Given that sealing would result in a loss of permeability, samples were analyzed for both gas and liquid permeability (Christenson et al., 2010). Gas permeability varied from $<0.001 \mathrm{mD}$ to $10.6 \mathrm{mD}$ while permeability values for liquids varied from $<0.001 \mathrm{mD}$ 
to $7.68 \mathrm{mD}$. Compared to fresh analogues from White Island, New Zealand, analyzed by Heap et al. (2017) with permeabilities of $1.80-11.25 \mathrm{mD}$, all samples display a decrease in permeability associated with alteration. This decrease is principally due to infilling of a network of fractures displaying a high degree of connectivity, the fractures consisting of an interconnected network of macro-scale fractures, micro-fractures, and nano-fractures.

The repeated eruptions at Turrialba between 2014 and 2019 suggest that sealing can be a recurring process at relatively short timescales. We propose that sealing will continue to result in phreatic eruptions at Turrialba as long as the magmatic-hydrothermal system remains in its current state with magmatic gases supplied by the crystallizing magma below. Additionally, hydrothermal sealing occurs by degrees, so a complete seal is not necessary in order for phreatic eruptions to be triggered. The presence of a near-continuous plume of gas present at Turrialba since 2014 indicates that sealing is partial (de Moor et al., 2016a). Given the knowledge that hydrothermal sealing is an ongoing and recurring process at Turrialba, continuous real-time monitoring may provide insight into seal rupturing and improve the early detection of these eruptions. 
Figure 9. Diagram of hydrothermal sealing at Turrialba adapted from Stix and de Moor (2018). Magmatic gases originating in the magma reservoir extending from between $1-10 \mathrm{~km}$ below the surface up to depths of $30 \mathrm{~km}$ (Di Piazza et al., 2015) enter the shallow hydrothermal system (Rizzo et al., 2016). Newly formed hot $\left(200-350^{\circ} \mathrm{C}\right)$, acidic $(\mathrm{pH}<4)$ fluids cause the dissolution of primary igneous minerals and the precipitation of hydrothermal minerals within the permeable conduit sealing fractures.

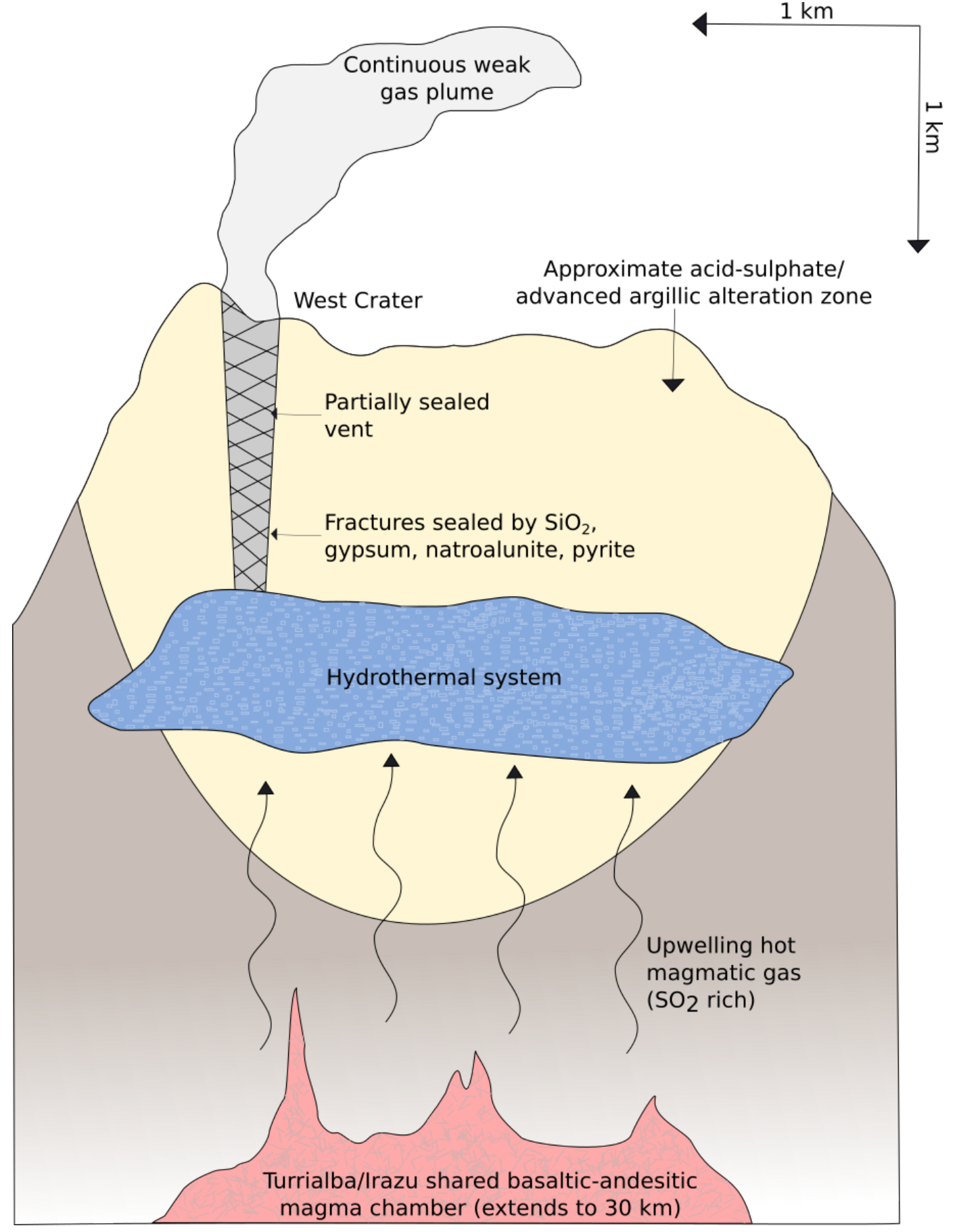




\subsection{Appendix I. Supplementary XRD Data}

Table 4. Detailed weight percent of matrix mineralogy of pyroclastic breccias determined by XRD. Data reduction was performed using PDF-4 Minerals 2019 RBD and PDXL2 Rigaku Data Analysis Software was used to confirm results. SiO 2 includes both quartz and cristobalite. Natroalunite includes natroalunite-1c, natroalunite-2c, and huangite.

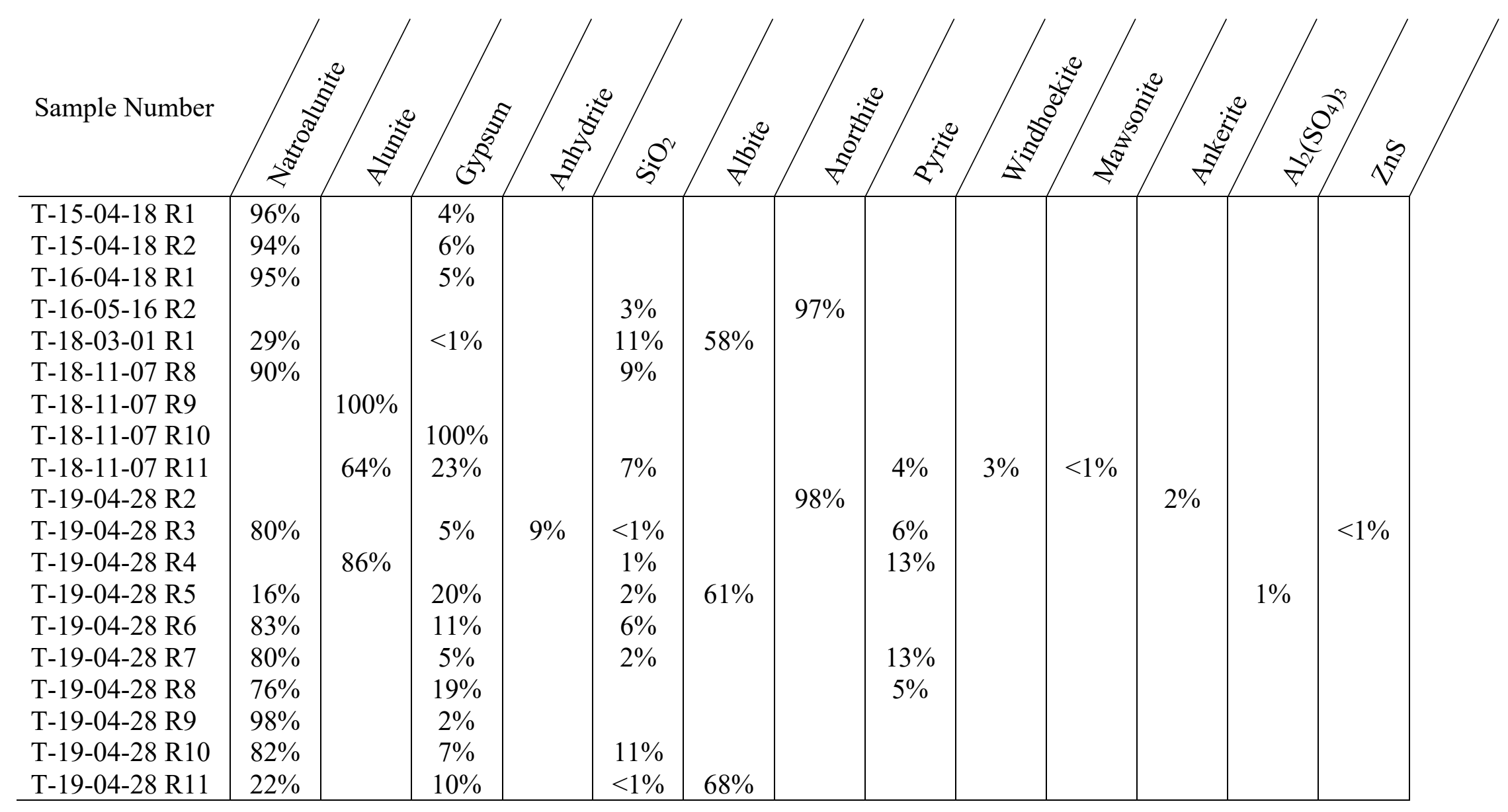




\section{Conclusions and Future Work}

This thesis has examined hydrothermal sealing as a mechanism responsible for repeated phreatic eruptions that have occurred at Turrialba since its reactivation, specifically between 2014 and 2019. A series of pyroclastic breccias believed to be pieces of failed seals were examined in a three-part study looking at mineralogy and alteration, permeability and porosity, and fracturing. The eruptive products examined display a high degree of hydrothermal alteration, namely acidsulphate alteration associated with the advanced argillic alteration facies. This alteration was found to result in an important loss of permeability due to the filling of a network of highly connected fractures. Both the alteration and the loss of permeability are indicative of hydrothermal sealing as the primary mechanism for the phreatic eruptions. These findings are consistent with fluids of $\mathrm{pH}<4$ and temperatures of $200-350^{\circ} \mathrm{C}$.

The knowledge that hydrothermal sealing has occurred at Turrialba repeatedly indicates that sealing is a recurring process over relatively short timescales (e.g., months to years). Given what is known of the magmatic-hydrothermal system at Turrialba, it is believed that sealing will continue for as long as the magmatic-hydrothermal system remains in its current phase. The continued study of Turrialba may provide further insight into the process of sealing as well as phreatic eruption precursors. The identification of reliable phreatic eruption precursors is essential to mitigating the dangers associated with them.

High-frequency gas monitoring may provide insight into gas signatures that may be interpreted as precursors. When sealing is incomplete and gases are still permitted to escape, a distinct set of precursory signals may be present as a result of the chemical composition of the seal. Furthermore, ongoing geophysical measurements including seismic and deformation monitoring, may provide further insight into sealing as a trigger for phreatic eruptions. These studies could 
provide crucial understanding of the timescales associated with seal formation, rupture and the resulting eruption. The application of these techniques at other volcanic systems experiencing sealing may provide crucial insight data for seal formation and rupturing processes to aid in the identification of reliable eruption precursors. This thesis has provided insight into sealing as a mechanism for phreatic eruptions in an effort to improve the understanding of possible precursory signals. 


\section{References}

Alvarado, G.E., 2009. Los Volcanes de Costa Rica: Geología, Historia, Riqueza Natural y du Gente, $3^{\text {rd }}$ ed., Editorial Universidad Estatal a Distancia, San José, Costa Rica.

Alvarado, G.E., Mele, D., Dellino, P., de Moor, J.M., Avard, G., 2016. Are the ashes from the latest eruptions (2010-2016) at Turrialba volcano (Costa Rica) related to phreatic or phreatomagmatic events? Journal of Volcanology and Geothermal Research 327, 407-415. https://doi.org/10.1016/j.jvolgeores.2016.09.003

Armstrong, D.C., 1995. Acid sulphate alteration in a magmatic hydrothermal environment, Barton Peninsula, King George Island, Antarctica. Mineralogical Magazine 59, 429-441. https://doi.org/10.1180/minmag.1995.059.396.05

Barberi, F., Bertagnini, A., Landi, P., Principe, C., 1992. A review on phreatic eruptions and their precursors. Journal of Volcanology and Geothermal Research 52, 231-246. https://doi.org/10.1016/0377-0273(92)90046-G

Barton, C.C., Hsieh, P.A. (Eds.), 1989. Physical and hydrologic-flow properties of fractures: Las Vegas, Nevada - Zion Canyon, Utah - Grand Canyon, Arizona - Yucca Mountain, Nevada, July 20 - 24, 1989, Field trip guidebook. American Geophysical Union, Washington, DC.

Campion, R., Martinez-Cruz, M., Lecocq, T., Caudron, C., Pacheco, J., Pinardi, G., Hermans, C., Carn, S., Bernard, A., 2012. Space- and ground-based measurements of sulphur dioxide emissions from Turrialba Volcano (Costa Rica). Bulletin of Volcanology 74, 1757-1770. https://doi.org/10.1007/s00445-012-0631-z

Christenson, B., Tassi, F., 2015. Gases in Volcanic Lake Environments, in: Rouwet, D., Christenson, Bruce, Tassi, Franco, Vandemeulebrouck, J. (Eds.), Volcanic Lakes, Advances in Volcanology. Springer Berlin Heidelberg, Berlin, Heidelberg, pp. 125-153. https://doi.org/10.1007/978-3-642-36833-2_5

Christenson, B.W., Reyes, A.G., Young, R., Moebis, A., Sherburn, S., Cole-Baker, J., Britten, K., 2010. Cyclic processes and factors leading to phreatic eruption events: Insights from the 25 September 2007 eruption through Ruapehu Crater Lake, New Zealand. Journal of Volcanology and Geothermal Research 191, 15-32. https://doi.org/10.1016/j.jvolgeores.2010.01.008

Christenson, B.W., Wood, C.P., 1993. Evolution of a vent-hosted hydrothermal system beneath Ruapehu Crater Lake, New Zealand. Bulletin of Volcanology 55, 547-565. https://doi.org/10.1007/BF00301808

de Moor, J. Maarten, Aiuppa, A., Avard, G., Wehrmann, H., Dunbar, N., Muller, C., Tamburello, G., Giudice, G., Liuzzo, M., Moretti, R., Conde, V., Galle, B., 2016. Turmoil at Turrialba Volcano (Costa Rica): Degassing and eruptive processes inferred from high-frequency gas monitoring. Journal of Geophysical Research: Solid Earth 121, 5761-5775. https://doi.org/10.1002/2016JB013150

de Moor, J.M., Aiuppa, A., Pacheco, J., Avard, G., Kern, C., Liuzzo, M., Martínez, M., Giudice, G., Fischer, T.P., 2016. Short-period volcanic gas precursors to phreatic eruptions: Insights from Poás Volcano, Costa Rica. Earth and Planetary Science Letters 442, 218-227. https://doi.org/10.1016/j.epsl.2016.02.056

de Moor, J.M., Muller, C., Pacheco, J., Mora, M., Avard, G., Aiuppa, A., Alvarado, G., Kern, C., Kelly, P., Pesicek, J., Wright, H., Pallister, J., Marso, J.,2017. 'The slow awkening of Turrialba Volcano: An increasing challenge for eruption forecasts', IAVCEI 2017. Portland, Oregon, 14-18 August. 
Di Piazza, A., Rizzo, A.L., Barberi, F., Carapezza, M.L., De Astis, G., Romano, C., Sortino, F., 2015. Geochemistry of the mantle source and magma feeding system beneath Turrialba volcano, Costa Rica. Lithos 232, 319-335. https://doi.org/10.1016/j.lithos.2015.07.012

Farquharson, J.I., Wild, B., Kushnir, A.R.L., Heap, M.J., Baud, P., Kennedy, B., 2019. Acidinduced dissolution of andesite: evolution of permeability and strength. Journal of Geophysical Research: Solid Earth 124, 257-273. https://doi.org/10.1029/2018JB016130

Fuller, C.M., Sharp, J.M., 1992. Permeability and fracture patterns in extrusive volcanic rocks: Implications from the welded Santana Tuff,Trans-Pecos Texas. GSA Bulletin 104, 14851496. https://doi.org/10.1130/0016-7606(1992)104<1485:PAFPIE>2.3.CO;2

Global Volcanism Program, 1980. Report of St. Helens (United States) (Squires, D., ed.). Scientific Event Alert Network Bulletin, 5:3. Smithsonian Institution, http://doi.org/10.5479/si.GVP.SEAN198003-321050.

Global Volcanism Program, 1980. Report of St. Helens (United States) (Squires, D., ed.). Scientific Event Alert Network Bulletin, 5:3. Smithsonian Institution, http://doi.org/10.5479/si.GVP.SEAN198005-321050.

Global Volcanism Program, 2012. Report in Turrialba (Costa Rica) (Wunderman, R., ed.). Bulletin of the Global Volcanism Network, 37:6. Smithsonian Institute. https://doi.org/10.5479/si.GVP.BGVN201206-345070.

Global Volcanism Program, 2017. Report in Turrialba (Costa Rica) (Crafford, A.E., and Venske, E., ed.). Bulletin of the Global Volcanism Network, 42:6. Smithsonian Institute. https://doi.org/10.5479/si.GVP.BGVN201706-345070.

Global Volcanism Program, 2018. Report in Turrialba (Costa Rica) (Venske, E., ed.). Bulletin of the Global Volcanism Network, 43:9. Smithsonian Institute. https://doi.org/10.5479/si.GVP.BGVN201809-345070.

Global Volcanism Program, 2019. Report in Turrialba (Costa Rica) (Venske, E., ed.). Bulletin of the Global Volcanism Network, 44:4. Smithsonian Institute. https://doi.org/10.5479/si.GVP.BGVN201904-345070.

Global Volcanism Program, 2019. Report in Turrialba (Costa Rica) (Venske, E., ed.). Bulletin of the Global Volcanism Network, 44:11. Smithsonian Institute. https://doi.org/10.5479/si.GVP.BGVN201809-345070.

Heap, M.J., Kennedy, B.M., 2016. Exploring the scale-dependent permeability of fractured andesite. Earth and Planetary Science Letters 447, 139-150. https://doi.org/10.1016/j.eps1.2016.05.004

Heap, M.J., Kennedy, B.M., Farquharson, J.I., Ashworth, J., Mayer, K., Letham-Brake, M., Reuschlé, T., Gilg, H.A., Scheu, B., Lavallée, Y., Siratovich, P., Cole, J., Jolly, A.D., Baud, P., Dingwell, D.B., 2017. A multidisciplinary approach to quantify the permeability of the Whakaari/White Island volcanic hydrothermal system (Taupo Volcanic Zone, New Zealand). Journal of Volcanology and Geothermal Research 332, 88-108. https://doi.org/10.1016/j.jvolgeores.2016.12.004

Heap, M.J., Troll, V.R., Kushnir, A.R.L., Gilg, H.A., Collinson, A.S.D., Deegan, F.M., Darmawan, H., Seraphine, N., Neuberg, J., Walter, T.R., 2019. Hydrothermal alteration of andesitic lava domes can lead to explosive volcanic behaviour. Nature Communications 10. https://doi.org/10.1038/s41467-019-13102-8

Henley, R.W., Berger, B.R., 2011. Magmatic-vapor expansion and the formation of highsulfidation gold deposits: Chemical controls on alteration and mineralization. Ore Geology Reviews 39, 63-74. https://doi.org/10.1016/j.oregeorev.2010.11.003 
Ikehata, K., Maruoka, T., 2016. Sulfur isotopic characteristics of volcanic products from the September 2014 Mount Ontake eruption, Japan. Earth Planet Sp 68, 116. https://doi.org/10.1186/s40623-016-0496-z

John, D.A., Sisson, T.W., Breit, G.N., Rye, R.O., Vallance, J.W., 2008. Characteristics, extent and origin of hydrothermal alteration at Mount Rainier Volcano, Cascades Arc, USA: Implications for debris-flow hazards and mineral deposits. Journal of Volcanology and Geothermal Research 175, 289-314. https://doi.org/10.1016/j.jvolgeores.2008.04.004

Kaneko, T., Maeno, F., Nakada, S., 2016. 2014 Mount Ontake eruption: characteristics of the phreatic eruption as inferred from aerial observations. Earth Planet Sp 68, 72. https://doi.org/10.1186/s40623-016-0452-y

Kato, A., Terakawa, T., Yamanaka, Y., Maeda, Y., Horikawa, S., Matsuhiro, K., Okuda, T., 2015. Preparatory and precursory processes leading up to the 2014 phreatic eruption of Mount Ontake, Japan. Earth Planet Sp 67, 111. https://doi.org/10.1186/s40623-015-0288-x

Kilgour, G., V. Manville, Pasqua, F.D., A. Graettinger, Hodgson, K.A., Jolly, G.E., 2010. The 25 September 2007 eruption of Mount Ruapehu, New Zealand: Directed ballistics, surtseyan jets, and ice-slurry lahars. Journal of Volcanology and Geothermal Research 191, 1-14. https://doi.org/10.1016/j.jvolgeores.2009.10.015

Klimchouk, A., 1996. The dissolution and conversion of gypsum and anhydrite. IJS 25, 21-36. https://doi.org/10.5038/1827-806X.25.3.2

Marinelli, G., 1969. Some geological data on the geothermal areas of Tuscany. Bull Volcanol 33, 319-333. https://doi.org/10.1007/BF02596726

Martini, F., Tassi, F., Vaselli, O., Del Potro, R., Martinez, M., del Laat, R.V., Fernandez, E., 2010. Geophysical, geochemical and geodetical signals of reawakening at Turrialba volcano (Costa Rica) after almost 150years of quiescence. Journal of Volcanology and Geothermal Research 198, 416-432. https://doi.org/10.1016/j.jvolgeores.2010.09.021

Meyer, C., Hemley, J.J. (1967) Wall rock alteration at Butte, Montana. Am Mineral 50:17171722

Minami, Y., Imura, T., Hayashi, S., Ohba, T., 2016. Mineralogical study on volcanic ash of the eruption on September 27, 2014 at Ontake volcano, central Japan: correlation with porphyry copper systems. Earth, Planets and Space 68. https://doi.org/10.1186/s40623016-0440-2

Miyagi, I., Geshi, N., Hamasaki, S., Oikawa, T., Tomiya, A., 2020. Heat source of the 2014 phreatic eruption of Mount Ontake, Japan. Bull Volcanol 82, 33. https://doi.org/10.1007/s00445-020-1358-x

Mordensky, S.P., Kennedy, B.M., Villeneuve, M.C., Lavallée, Y., Reichow, M.K., Wallace, P.A., Siratovich, P.A., Gravley, D.M., 2019. Increasing the Permeability of Hydrothermally Altered Andesite by Transitory Heating. Geochemistry, Geophysics, Geosystems 20, 5251-5269. https://doi.org/10.1029/2019GC008409

Mordret, A., Jolly, A.D., Duputel, Z., Fournier, N., 2010. Monitoring of phreatic eruptions using Interferometry on Retrieved Cross-Correlation Function from Ambient Seismic Noise: Results from Mt. Ruapehu, New Zealand. Journal of Volcanology and Geothermal Research 191, 46-59. https://doi.org/10.1016/j.jvolgeores.2010.01.010

Mori, T., Hashimoto, T., Terada, A., Yoshimoto, M., Kazahaya, R., Shinohara, H., Tanaka, R., 2016. Volcanic plume measurements using a UAV for the $2014 \mathrm{Mt}$. Ontake eruption. Earth Planet Sp 68, 49. https://doi.org/10.1186/s40623-016-0418-0 
Oikawa, T., Yoshimoto, M., Nakada, S., Maeno, F., Komori, J., Shimano, T., Takeshita, Y., Ishizuka, Y., Ishimine, Y., 2016. Reconstruction of the 2014 eruption sequence of Ontake Volcano from recorded images and interviews. Earth Planet Sp 68, 79. https://doi.org/10.1186/s40623-016-0458-5

Reagan, M., Duarte, E., Soto, G.J., Fernandez, E., 2006. The eruptive history of Turrialba volcano, Costa Rica, and potential hazards from future eruptions. Geological Society of America Special Papers 235-253. https://doi.org/10.1130/2006.2412(13)

Rizzo, A.L., Piazza, A.D., Moor, J.M. de, Alvarado, G.E., Avard, G., Carapezza, M.L., Mora, M.M., 2016. Eruptive activity at Turrialba volcano (Costa Rica): Inferences from $3 \mathrm{He} / 4 \mathrm{He}$ in fumarole gases and chemistry of the products ejected during 2014 and 2015. Geochemistry, Geophysics, Geosystems 17, 4478-4494. https://doi.org/10.1002/2016GC006525

Rodriguez, A., van Bergen, M.J., 2017. Superficial alteration mineralogy in active volcanic systems: An example of Poás volcano, Costa Rica. Journal of Volcanology and Geothermal Research 346, 54-80. https://doi.org/10.1016/j.jvolgeores.2017.04.006

Soto, G., 1988. Estructuras volcano-tectonicas del volcan Turrialba, Costa Rica, America Central 3, 163-175.

Stix, J., de Moor, J.M., 2018. Understanding and forecasting phreatic eruptions driven by magmatic degassing. Earth, Planets and Space (Online); Heidelberg 70, 1-19. http://dx.doi.org/10.1186/s40623-018-0855-z

Stoffregen, R.E., 1987. Genesis of acid-sulfate alteration and $\mathrm{Au}-\mathrm{Cu}-\mathrm{Ag}$ mineralization at Summitville, Colorado. Economic Geology 82, 1575-1591. https://doi.org/10.2113/gsecongeo.82.6.1575

Stoffregen, R.E., Alpers, C.N., Jambor, J.L., 2000. Alunite-Jarosite Crystallography, Thermodynamics, and Geochronology. Reviews in Mineralogy and Geochemistry 40, 453479. https://doi.org/10.2138/rmg.2000.40.9

Vaselli, O., Tassi, F., Duarte, E., Fernandez, E., Poreda, R.J., Huertas, A.D., 2010. Evolution of fluid geochemistry at the Turrialba volcano (Costa Rica) from 1998 to 2008. Bulletin of Volcanology 72, 397-410. https://doi.org/10.1007/s00445-009-0332-4

Whattam, S.A., Stern, R.J., 2016. Arc magmatic evolution and the construction of continental crust at the Central American Volcanic Arc system. International Geology Review 58, 653-686. https://doi.org/10.1080/00206814.2015.1103668

Zimbelman, D.R., Rye, R.O., Breit, G.N., 2005. Origin of secondary sulfate minerals on active andesitic stratovolcanoes. Chemical Geology 215, 37-60.

https://doi.org/10.1016/j.chemgeo.2004.06.056 